\title{
KAMU YAYINCILIĞINDA ÖTEKILEŞTIRME KÜLTÜRÜ: TRT1 VE 16 NISAN REFERANDUMU ÖRNEKLIĞi
}

Ferhat ZENGiN ${ }^{1}$

Bahadır KAPIR $^{2}$

\begin{abstract}
öz
Kamu hizmet yayıncılığı kavramının tüm dünyada geçerli tek bir tanımı olmasa da genel olarak kavram; finansmanı kamu tarafından sağlanan, kamu yararını gözeterek yayın yapan ve bu yayınların denetiminin kamu tarafından yapıldığı yayın biçimini ifade etmek için kullanılır. Bu nedenle kamu yayıncılığının en belirgin özelliği yayıncılık ve ekonomik anlamda hiçbir otoriteye bağlı olmamasıdır. Kamu yayıncılığı bağlamında yayın yapan kurumun toplumun tüm kesimlerine tarafsız olarak yaklaşarak toplumu eğlendirici, bilgilendirici ve eğitici amaçlar doğrultusunda yayın yapması beklenir. Hukuksal olarak devlete bağlı bulunan ve kamu iktisadi teşebbüsü olarak kurulan televizyon kanalları resmî ideolojinin belirlediği sınırlar ekseninde yayınlarını gerçekleştirdiği ve bu ideolojik çerçeve dâhilinde gerek etnik gerekse dini yapıda azınlık olarak genel bir kavramda tanımlanan belirli bir topluma veya gruba yayınlarında eşit söz hakkı tanımadığı ve bu grupları ötekileştirdiği için eleştirilmektedirler. Bu çalışmanın konusu 16 Nisan Anayasa Referandumu sürecinde bir kamu kuruluşu olan TRT1'de yayınlanan ana haber bültenlerinde toplumun farklı düşünce yapısına sahip kesimlerini temsilen siyasi partilerin ve çeşitli ideolojik görüşe sahip olan grupların düşüncelerinin ve görüşlerinin nasıl yer aldığı ve kamuya nasıl yansıtıldıkları olmuştur. Zaman aralığı bağlamında referandumla ilişkili olarak 1 Nisan ve 15 Nisan tarihleri seçilmiş ve bu aralıktaki hafta içi yayınlanan 'Erhan Çelik ile TRT Ana Haber' bültenleri içerik analizi yöntemi ile incelenmiştir. Böylelikle, farklı siyasi partilerin, sivil toplum örgütlerinin veya eleştirel yaklaşımların TRT1 ana haber bültenlerinde nasıl temsil edildikleri ortaya çıkarılmaya çalışılmıştır.
\end{abstract}

Anahtar Kelimeler: Kamusal Yayıncılık, Referandum, Anayasa, Ötekileştirme, Kamusal Alanda Temsil.

\section{MARGINALISATION CULTURE IN PUBLIC BROADCASTING: TRT1 AND 16 APRIL REFERENDUM CASES}

\begin{abstract}
It is not possible to provide a global definition for the public broadcasting concept. However, this concept is often used for representing broadcasting type that is financed by the public, that favours public interest, and that had audited broadcasts by the public. Therefore, the most distinct property of public broadcasting is it is not linked to any type of authority in terms of broadcasting and economy. In terms of public broadcasting, it is expected that broadcasting institute considers all segments of the society for broadcasting to entertain, inform and educate the

1 Dr. Öğr. Üyesi, İstanbul Gelişim Üniversitesi Uygulamalı Bilimler Yüksekokulu, fzengin@gelisim.edu.tr, ORCID: 0000-0002-6785-3257

2 Doktora Öğrencisi, Marmara Üniversitesi Sosyal Bilimler Enstitüsü İletişim Bilimleri, bahadirkapir@gmail.com, ORCID: 0000-0002-4602-9859
\end{abstract}


ZENGIN, Ferhat ve KAPIR, Bahadır (2020). Kamu Yayıncılığında Ötekileştirme Kültürü: TRT 1 ve 16 Nisan Referandumu Örnekliği, Gümüşhane Üniversitesi İletişi̧m Fakültesi Elektronik Dergisi (e-gifder), 8 (2), 1145-1178

society. Television channels that are operating legally under state and established as public economic enterprise are criticised as these channels broadcast along an axis determined by the limits of official ideology and within this framework of ideology, not providing equal right of speaking to ethnic and religious minorities or alienated such minorities with hate speech. As a part of this ideologic "equal distance", this study aims to discover how ideas and opinions of political parties that represent different segments of society and different groups are represented in evening news broadcast in TRT1 as a public institution and how these ideas and opinions are reflected across the public during 16 April constitution referendum process. In terms of timeframe related with the referendum, 1 April and 15 April and "TRT News with Erhan Çelik" broadcast during weekdays are selected and evaluated with content analysis method. Thus, the representation of different political parties, NGOs and critical approaches in TRT1 evening news are analysed.

Keywords: Public broadcasting, Referendum, Constitution, Marginalisation, Representation in Public Space.

\section{Giriş}

Düşüncelerimizi ve fikirlerimizi diğer insanlar ile paylaşma duygusu tarih boyunca iletişim ve iletişim araçlarının gelişimini sağlamıştır. Özelikle toplum arasındaki iletişimi ve haberleşmeyi kuvvetlendiren kitle iletişim araçlarının gelişimi ile beraber bu araçların kitleleri yönlendirme, belirli bir düşünce akımı etrafında şekillendirme ve manipüle etme gücü de ortaya çıkarmıştır. Dolayısıyla kitle iletişim araçları toplumların bilgi, duygu, davranış ve düşünce yapılarını etkilemede tek unsur olmasa bile önemi büyük bir role sahiptir (Karaboğa, 2010: 2). Zamanının egemen düşüncesine sahip olan sınıf, fikir ve görüşlerini topluma yaymak, iktidar erkini elinde tutmak ve bu erki meşrulaştırmak için kültürel ve ideolojik aygit olarak tarihsel süreç içerisinde matbaanın icadından internetin icadına kadar var olan geniş bir yelpazede çeşitli kitle iletişim araçlarını kullanmıştır (Yaylagül, 2016: 113-114). $\mathrm{Bu}$ ikna etme ve etkileme sürecinde egemen ideolojik söylemler ekseninde oluşturulan bilgi ve haber akışı kontrol edilerek toplumlar kitle iletişim araçları vasıtası ile manipüle edilmeye çalışılmış, belli kalıplara sokularak yönlendirilmiş (Schiller, 2005: 13) ve toplumun belirli bir kesimi tarafindan öteki kesimini bask1 altında tutmak için kullanılmıştır (Kocabaşoğlu, 1980: 1).

Kitle iletişim araçlarının toplum ve bireyler üzerindeki manipüle edici gücünün keşfedilmesi bu araçların birer ideolojik aygıt olarak kullanılmasına neden olmuştur. Bu bağlamda I. Dünya Savaşı esnasında halkı manipüle etmek, iktidarın çıkarlarına hizmet edici bir şekilde bilgi vermek için hem yazılı basın hem de gelişen teknoloji ile hayat bulan radyo yayınları birer propaganda aracı olarak kullanılmaya 
başlanmıştır (Avşar, 1990: 66). II. Dünya savaşı sonrasında ise aynı amaçla -özellikle seçim dönemlerinde- halka ulaşmak için televizyon yayınları kullanılmaya başlanmıştır. Bu süreçte kitle iletişim araçlarının gücünü keşfeden toplumsal sınıflar bu araçları kendi çıkarları doğrultusunda kullanarak; halkı etkilemeye, yönlendirmeye ve kendi fikir çerçevesinde olmayan görüşleri/grupları ötekileştirmeye çalışmışlardır (Taşcıoğlu, 2009: 5).

Kitle iletişim araçlarının tek yönlü propaganda aracı olarak kullanılması, otoriter rejimlerin tüm iletişim olanaklarını kendi çıkarları doğrultusunda şekillendirmesi tarafsız bir yayın kuruluşuna olan ihtiyacı ortaya çıkarmıştır (Aydoğan, 2004: 48). Kamu hizmet yayıncılı̆̆ı bu ihtiyaçtan doğan bir kavram olarak esas gayesi halkı bilgilendirmek, eğlendirmek ve eğitmek olarak tanımlanmıştır. Bu hizmetleri yerine getirmek için kamusal yayıncılık faaliyetini sürdüren kurumların bünyesinde oluşturulan program ve haber içeriklerinin tarafsız bir yapıda olması ve farklı siyasal görüşlere eşit biçimde yayın akışlarında yer vermesi bu kurumların esas gayesi olarak belirlenmiştir (Kaya R., 1985: 78). Bu eksende tarafsız ve özgür yayıncılık yapması beklenen kamu yayın kuruluşların halktan toplanan vergiler veya çeşitli bandrol ücretleri ile finanse edilerek siyasi iktidarın ve maddi gücü elinde bulunduran zümrenin boyunduruğundan kurtarılması hedeflenmiştir. Fakat bu kurumların hukuksal statüsü kendini devletin çıkarlarının koruyucusu olarak gören mevcut siyasi yapıya yasal olarak hep bağlı durumda kalmıştır (Mutlu, 1999:24). Bu gelişmeler çerçevesinde Türkiye'de vatandaşların tarafsız bir şekilde bilgilendirilmesi, eğitilmesi ve eğlendirilmesi amacıyla "Türkiye Radyo Televizyon Kurumu (TRT), devlet adına radyo ve televizyon yayınlarını gerçekleştirmek amacıyla 01 Mayıs 1964'te, özel yasayla özerk tüzel bir kişiliğine sahip olarak kurulmuştur" (TRT).

Türkiye'de gerek devlet radyosunun yayınları gerekse kamusal yayıncılık kavramı ekseninde gerçekleştirilen televizyon yayınları birçok yönden eleştirilere maruz kalmıştır. $\mathrm{Bu}$ eleştiriler çoğunlukla iktidar erkini elinde bulunduran siyasi partilerin, radyo yayınlarını ve televizyon yayınlarını birer propaganda aracı olarak kullanması üzerine yoğunlaşmıştır. Bu süreçte 1946 ve 1960 yıllarında Türkiye'de yapılan radyo yayınları iç politika açısından iktidar ve muhalefet partilerinin 
çekişmelerinin odak noktası olmuştur. Radyo yayınlarının tek partili dönemde başlamasına rağmen siyasi ortamın yapısından dolayı radyonun ideolojik işlevi pek fark edilmemiştir. Fakat çok partili ortama geçilmesi ile radyonun propaganda aracı olarak kullanılmasına başlanmıştır. İktidarın hizmetinde bulunduğu eleştirisiyle radyoya ilişkin 'devlet radyosu', 'rejim meselesi', 'partizan radyo', 'vatan cephesi' gibi kavramlar kullanılmaya başlanmıştır (Kocabaşoğlu, 1980: 344). ${ }^{3}$ Radyo yayınlarına yöneltilen bu eleştiriler, 1968 yılında bir devlet kurumu olan TRT tarafinda televizyon yayınlarının başlamasından belli bir süre sonra bu defa televizyon yayıncılığı için yöneltilmiştir. 1972 yılında yapılan anayasa değişikliği ile tarafsız bir kamu iktisadi kuruluşu olarak tanımlanan kurum kuruluşundan bu yana protokol haberciliği yaptığg, toplumun ihtiyaç duyduğu haberleri vermekten ziyade devletin verilmesini uygun gördüğü haberleri verdiği (Aksüt, 2011: 3), siyasal iktidarların kurumu siyasi propaganda aracı olarak kullandığı, seçim zamanlarında özellikle TRT haber merkezinin siyasi çevre tarafından iktidarın basın-yayın organı (Canoruç, 2009: 295) gibi hareket ettiği, toplumun ve kamunun yararını gözetmekten çok özel televizyonların yayın hayatına başlaması ile birlikte düşen reklam gelirlerini yükseltmek için birer ticari şirket gibi işletildiği ve bu doğrultuda yayın içeriğini özel kanalların içeriklerine benzer bir şekilde düzenlediği (Eren, 2008: 26), dolaylı yoldan dahi olsa etnik gruplar ve özellikle sol görüşü temsil eden ideolojik ve siyasi yapılara ayrımcılık yaptığı ve bu grupları ötekileştirerek yok saydığı (Neşe, 1996: 508-509) gibi geniş bir yelpazede birçok konu hakkında eleştirilmiştir.

Kamu yayıncılığı yapan kurumlar, halkın çıkarlarını korumak ve halkın tüm kesimlerini kamusal alanda temsil etmek ve bu çerçevede yayın yapmak için organize edilmişlerdir. Bu doğrultuda '16 Nisan Anayasa Referandumu' sürecinde TRT1'in 1 Nisan ve 15 Nisan tarihleri arasında hafta içi yayınlanan ana haber bültenlerini içerik analizi yöntemi ile incelediğimiz bu çalışmada mezkûr tarihler arasında TRT1'in toplumun farklı düşünce yapısına sahip kesimlerini temsilen siyasi partilere, sivil toplum örgütlerine ve gruplarına ana haber bülteninde ne kadar süre

\footnotetext{
${ }^{3}$ Uygur Kocabaşoğlu iktidar partisine (Demokrat Parti) bu eleştirilerini yöneltirken, aslında muhalefet partisi (Cumhuriyet Halk Partisi) ile iktidar partisinin radyoyu algılayış biçiminde temel bir fark olmadığıı vurgulamıştır. Sadece bu araçlardan yararlanmada birtakım farkıııkların ön plana çıktığııı söylemektedir (Kocabaşoğlu, 1980: 344-345).
} 
ayırdığ 1 ve bu süreler zarfinda bu grupların bülten içinde nasıl temsil edildiği ve ekrana nasıl yansıtıldı̆̆ incelenmiştir.

\section{Medya Ve Ötekileştirme Söylemleri}

"İnsanların topluluk halinde yaşamaya başladığı tarihten itibaren var olan 'biz' ve ‘ötekiler' kavramı” (Vardal, 2015: 135) bireyin kendini ve karşısındakini tanımladığ1 bir kimlik inşası sürecidir (Güliz, 2009: 33). Bu süreçte Edward Said'in belirttiği gibi "kimliğin inşası karşıtların, 'ötekiler'in belirlenmesini gerektirir” (346347). Aidiyet, etnik kimlik, ulusal kimlik, cinsiyet, dinsel yap1 gibi kavramlar etrafında ‘ben' tasavvuru şekillenirken (Arar, 2009: 3) özne olarak ‘ben’ kavramı kendini tanımlayabilmek için ötekine ihtiyaç duymaktadır (Zizek, 2011: 97). 'Ben’ öteki ile ilişki kurduğu sürece var olur. Bu bağlamda tanımlanan “'Öteki' en temel noktada bir farklılaştırma eyleminin sonucudur" (Nahya, 2011: 30).

Ötekileştirme sürecinin toplum üzerindeki etkisine genel bir perspektiften bakıldığında ise ben ve öteki algısının üç şekilde tanımlandığı görülecektir. Birinci olarak mutlak bir 'ben' algısı ve mutlak bir 'öteki’ algısının karşı karşıya gelmesi ile oluşan çatışma ortamında mutlak manada iyi, haklı ve mükemmel olan 'ben' karşısına içinde kötü, eksik ve haksız gibi zıtlıkları barındıran 'öteki’ konulmaktadır. İkinci olarak ise ‘ben'in karşısına yok sayılan ve yok edilmek istenen öteki kavramı konumlandırılır. Üçüncü ve son olarak ben ve öteki kavramlarının içi boşaltılarak post modern dünya yapısı tarafindan üretilen sahte kimlikler ile bireye ideolojik yapı altında uygun görülen 'ben’ ve ‘öteki’ tanımlaması dayatılmaktadır (Kalın, 2016: 455). Örneğin modernist düşünce yapısı ile 'batı' kendini yegâne iyi olarak nitelenmiş, üst konuma yerleştirilmiş ve diğer 3. dünya ülkelerini ancak batıyı taklit ederek ilerleyebilecekleri düşüncesiyle ötekileştirilmiştir (Güliz, 2009: 23; Düzgit, 2014: 83). Öteki kavramı üzerinden 'kendi' kimliğini tanımlamak yalnızca batılı toplumlar için geçerli değildir. Bu olgu Antik Yunan düşünce dünyasından beri sorgulanmıştır (Uluç ve Soydan, 2007: 35).

Öteki 'ben' gibi olmaya zorlanan, sesi kısılan veya görmezden gelinen olmuştur. Güçlü ben tasavvuru karşısında ezilen öteki ya kültürel anlamda tarih sahnesinden silinmiş ve kökleri kazınmış ya da 'güçlü ben'in içinde eritilmiş ve 
homojenleştirilmiştir (Schnapper, 2005: 26). Post-modern dönemde öteki siyahi, Yahudi, doğulu ${ }^{4}$ veya sosyalist gibi gruplar ile tanımlanmaktansa feminist, çevreci, milliyetçi, muhafazakâr, demokrat, modernist gibi daha bireysel bir yapıda ve ait olunan kültürel alt kimlikler çerçevesinde tanımlanmaktadır (Poyraz \& Arıkan, 2004: 14). Bu ayrım ve tanımlamalar çoğu zaman etnik köken ve dini kimlik üzerinde kurgulanırken modern toplumlarda devletin ve egemen ideolojinin hizmetkârı olarak resmî ideolojinin belirlediği kalıplar dâhilinde bizden olmayanın veya ait olduğumuz topluma ve bu toplumun normlarına uymayanın vatan haini, hırsız, gâvur ve benzeri gibi belirli kalıplara sokularak ötekileştirilip, düşmanlaştırılmasında en etkin araç olan medya tarafindan toplumun ve bireylerin düşünce yapısı şekillendirilmektedir (Arar \& Bilgin, 2010: 5). Toplumları, gündemi saptayarak ve belirleyerek kapsamlı ve kalıcı, köklü ve geri dönülmez bir biçimde şekillendiren medya (Meyer, 2004: 9), toplumsal sınırları ve normları belirleyerek 'öteki'nin inşasında toplum tarafindan benimsenecek imgeleri yaratır, bireyleri ve toplumları konumlandırır. Medya tarafindan tanımlanan ve yeniden dolaşıma sokulan Öteki; 'benlbiz' den olmayanı, farklı olanı temsil ederken, dışlama ve aşağılanmaya maruz kalmaktadır (Torun, 2015: 2). Bu söylemler siyasetten spora, etnik kimlikten cinsel kimliğe kadar uzanan geniş bir yelpazede sürer. Çoğunluğu, iktidarı veya gücü elinde bulunduranlar kendi görüşünü ötekine dayatma yoluna gider. Bu dayatma sadece klasik sansür sistemine maruz kalmak değildir; senden olmayanı yok saymak, hiçbir söz hakkı tanımamak da ötekine yapılan bir ayrımcılıktır (İnceoğlu ve Çoban, 2014: 54-55; Güreşçi, 2007: 72).

Farklı görüneni veya düşüneni dışlama, düşman haline getirme ve yok sayma olarak tanımlayabileceğimiz ötekileştirme sürecini medya organları ürettikleri haberlerde haberin değerini arttıran birer unsur olarak görmekte ve ötekileştirdiği grubu toplumsal bir hedef haline getirmektedir (Bayram, 2015: 1). Medya belirli grupları veyahut düşünce akımlarını yok sayarak ya da sınırlı biçimde yayın

\footnotetext{
${ }^{4}$ Oryantalist düşünce daha geniş bir coğrafyayı ötekileştirmeyi temsil eden bir yapıdır. Diğer ayrımcı düşünce yapılarının aksine oryantalizm düşüncesi küçük bir grubu değil, birçok ülkeyi hatta kıtaları kapsayan bir ötekileştirme biçimidir. Bu düşünceye göre doğu zavallı ve gizemli bir yerdir (Çapar, 2006).
} 
akışlarında yer vererek, özellikle olumsuzlukları konu ederek, bireyleri ve toplumu ayrımcı nitelemeler ile sürekli göz önünde bulundurarak ve çeşitli gruplar hakkında nefret söylemi geliştirerek bireyin fikir dünyasını belirli kalıplar çerçevesince şekillendirir (Celenk, 2010: 224-226) karşıtını ötekileştirir ve kontrolünü elinde bulundurduğu teknolojik aygitlar ile "bireyi devletin siyasal ideolojisine uydurur, tüm yurttaşları basın, radyo, televizyon ile günlük milliyetçilik, şovenizm, liberalizm, ahlakçılık vb. dozları ile besler" (Althusser, 2002: 43). Bu kalıplar dışında kalan, ise olumsuz, alaycı, küçük düşürücü söylemler ile ötekileştirilerek düşmanlaştırılır (İnceoğlu, 2013: 77).

\section{2. İktidar, Medya Ve Haber Üretimi}

Hükümetler ile medya arasında iki temel yönden etkileşim bulunmaktadır. Siyasi erki elinde bulunduran zümre halkın hassas olduğu dini, siyasi ve etnik konularda kamusal düzeni bozabilecek ve kamunun zararına olabilecek yayınları kontrol altına alabilmek için çıkarttıkları kanunlar ile ülke çapında yayın yapacak olan medya kurumlarını denetlemeyi amaçlamaktadır. Aynı zamanda bu zümre ikinci sebep olarak kitle iletişim araçları vasıtası ile geniş izleyici kitlelerine ucuz ve kolay yoldan ulaşmak arzusu içindedir (Çaplı, 2002: 33). Siyasiler propaganda faaliyetlerini sürdürmek ve yaptıkları veya vaat ettikleri icraatlarını duyurabilmek için medya yoluyla kitlelere ulaşmaya çalışırlar (Çaplı, 1995: 92). Siyasi erki elinde bulunduran zümre hali hazırda sahip olduğu iktidarı korumak için gerek kamu kurumu olarak gerekse ticari bir şirket olarak faaliyet gösteren televizyon kanalları tarafında üretilen haberlere, dizilere, çeşitli programlara müdahale ederek içeriğin yapısını değiştirirler. Egemen ideolojinin çıkarları ekseninde müdahale edilen ve yeniden şekillendirilen televizyon içerikleri bu zümreden aldığı bilgileri yine bu erkin ideolojisine göre ayıklar, süzgeçten geçirir ve topluma sunar (S. Herman, 2003: 224).

Özellikle kamu hizmet yayıncılı̆̆ faaliyetinde bulunan kanallara yapılan bu müdahaleleri John Keane şu sözler ile eleştirmiştir: "Kamu hizmet yayıncılı̆̆ tüketicinin seçenekleri açısından sistematik ve keyfi bir sansür gibi işler. Hükümetin eli, ayrıcalıkların ve siyasal yardımların sorumluluksuz dağıtıcısıdır. Kamu hizmeti yayıncılığı ifade özgürlüğünü tehdit eder. Bizim için neyin iyi olduğunu bize söyler. 
Bizi yasal kurallarla sindirir." (Keane, 1993: 65). Freidhelm Neidhardt ise kamusal iletişimin eşitlikçi ve demokratik çerçevede yayınlarını gerçekleştirebilmesi için yurttaşların siyasal arenada gerçekleşen tüm olaylardan tarafsız ve gerçekçi bir şekilde haberdar edilmesi ve bu süreçte verilen bilgilerin doğru ve güvenilir olmak zorunda olduğunu söyler (Meyer, 2004: 28).

Medya gerçekliği hiçbir zaman olduğu gibi topluma yansıtmaz. Medya ve özellikle görsel anlamda güçlü olan televizyon ile sahte bir gerçeklik inşa edilir. Tekrardan kodlanan sahte gerçekliğe ideolojik bir anlam yüklenir (Fiske, 1997: 31). Yeniden anlam kazandırılarak belli bir ideoloji çerçevesince üretilen haberler sayesinde iktidar ilişkileri toplum tarafında meşrulaştırılır. Yapılan haberler iktidar ve onun ideolojisine hizmet edecek şekilde tekrardan üretilir (Hall, 1997: 93). Gerçekliğin haber boyunca tekrardan inşası ile bireyler içinde bulunduğu ahvalde medya aracılığı ile dünyayı kendinden istenildiği şekilde yorumlamaya ve anlamlandırmaya başlar (Dursun, 2004: 43).

Chomsky devlet ve şirketlerin medyayı nasıl yönlendirdiği ve propaganda amaçlı olarak nasıl kullandıklarını göstermeye çalışmıştır. Ona göre "medya, haberlerin ve çözümlemelerin çatısını yerleşik ayrıcalıkları destekleyen bir çerçeve kurarak ve bu doğrultuda her türlü tartışmayı sınırlayarak, birbiriyle sıkı sıkıya kaynaşmış olan devletin ve şirketlerin çıkarlarına hizmet etmektedir" (Chomsky, 1993: 23). Golding ve Murdock (2008: 47) ise televizyon haberciliğinin üç şekilde ideolojik olarak gerçekleştiğini söyler. İlk olarak televizyon haberciliği izleyicinin dikkatini toplumsal çatışmanın yöneltildiği, çözüldüğü olaylara ve kurumlara odaklar. İkinci olarak yapılan haberler toplumda egemen olan fikirler çerçevesinde şekillenir. Bu haberlerde tarafgirlikten ve olası bir tartışma ortamından kaçınmak için üretilen haberler toplum tarafindan kabul edilen inanç ve düşüncelere dayanır. Üçüncü ve son olarak üretilen televizyon haberleri tarihsel olarak ve bağlı oldukları kurumların yapılarından dolayı toplumsal değişimleri ve iktidarın işleyişini göstermez. İktidarlar için olası en büyük tehlike toplumun sistem veya kuralların değişebileceğine, sorgulanabileceğine inanması veya bu düşüncenin toplum tarafından düşünülmeye başlanmasıdır. Kitle iletişim araçları vasıtası ile üretilen 
haberler toplumu var olan dünyanın veya sistemin asla değiştirilemeyeceğine veyahut değiştirilse bile bunun kötü sonuçlar doğuracağına inandırır.

Hükümet, iş dünyasının önde gelen isimleri, medya kuruluşlarının sahipleri, üst düzey yöneticiler neyin haber olup olmadığını belirleyerek (Yaylagül, 2016: 179) medya aracılığı ile halka ulaşılması istenilen ve buna ek olarak halka ulaşmasında herhangi bir sakınca görülmeyen mesajları, üretilen sembolleri belirlerler. Bir otosansür örneği olarak değerlendirebileceğimiz bu ileti sırasında medya, toplumu eğlendirmek, avutmak, bilgi vermek ve egemen ideolojiye bağlı kalarak toplum arasında genel kabul görmüş inançları ve davranış kodlarını pekiştirmek gibi kendine verilen görevleri yerine getirerek bizatihi istenilen toplum modelinin yapılandırılmasında etkilidir. Halkın toplumsal olgu ve olaylarda bilgi sahibi olmak için izlediği haberler, medya üzerinde söz hakkı olanlar tarafından yeniden üretilerek muhalefet ötekileştirilirken, hükümetin çıkarlarına hizmet edecek bir biçime bürünür. Medya üzerinde söz hakkına sahip olan gerek ekonomik gerekse siyasi gücü elinde bulunduran gruplar tarafından üretilen içerikler ve özellikle haberler kontrol mekanizmalarından geçer ve topluma sunulur. (Edward ve Chomsky, 1988: 1-2). Bu amaç doğrultusunda haber içeriklerinde esas verilmek istenen mesaj kalın puntolarla izleyicinin/okuyucunun tüm dikkatini çekecek biçimde düzenlenir. Böylelikle izleyicinin veya okuyucunun haberi kaçırması veya istenilen mesajı alamaması durumu imkânsızlaşır (Schiller, 2005: 130). Böylelikle medya, kendi gündemini yaratırken, toplumsal bağlamdan koparak hem örtük hem açık biçimde rrkçılık, etnik önyarg1, zenofobi (yabancı korkusu-nefreti), antisemitizm gibi kavramlarla tanımlanabilecek türden nefret söylemlerini üreterek bireyleri ve toplumları ötekileştirirken (İnceoğlu, 2012: 16) "haber medyası, ötekini, dışarıdakini, ait olmayanın imajını sürekli çatışma ve kalabalık kitleler halinde, tehdit unsuru olarak algilatacak imgeyi oluşturacak şekilde temsil ederek, potansiyel tehlike olarak göstermektedir" (Mora, 2008: 206).

\section{Araştırmanın Amacı Ve Önemi}

Bu çalışmada 16 Nisan 2017 Anayasa Referandumu çerçevesinde bir kamu iktisadi kuruluşu olan TRT1'in ana haber bültenlerinde hangi partiye ve parti liderlerine nasıl ve ne kadar yer verdiği, yayınlanan haberlerde en çok hangi konular 
üzerinde durulduğu, haberin aktörünün hangi söylemler ekseninde nasıl temsil edildiği, haberin yayınlanış biçimi, partileri konu alan haberlerin bülten içindeki yayın sırasının nasıl gerçekleştiği ve bu haberlerin verilişinde görsel olarak hangi materyallerin kullanıldığı detaylı bir şekilde incelenmiştir. Çalışma; TRT1'nin bir kamu kurumu olarak yayınlarını 6112'nolu hem kamu hem de ticari yayın faaliyetlerinin düzenlenmesini içeren kanunun yayın hizmetleri; “...siyasî ve felsefî düşünce, mezhep ve benzeri nedenlerle ayrımcılık yapan yayınları içeremez ve teşvik edemez...” ve “...siyasî partiler ve demokratik gruplar ile ilgili tek yönlü veya taraf tutar nitelikte yayın yapamaz" maddelerine uygun olarak yayınlarını sürdürmediği, toplumun tüm kesimlerine hitap edebilme yetisine sahip olmadığı, haber bültenlerinde niteliksel ve niceliksel olarak muhalefet-iktidar dengesini kuramadı̆̆ 1 , kamu hizmet yayıncılığ 1 işlevlerini yerine getiremediği ve siyasal iktidarların etkisi altında yayınlarını sürdürdüğ̈ ve bu bağlamda yayınlarında örtülü olarak ötekileştirme yaptığı varsayımından hareket etmektedir.

Bu bağlamda çalışmanın amacı; demokratik bir seçim ortamında bir kamu hizmeti yayıncısı TRT1'in haber bültenleri vasıtası ile “...siyasî partiler ve demokratik gruplar ile ilgili tek yönlü veya taraf tutar nitelikte yayın yapamaz"5 hükmüne uyup uymadığını; toplumu oluşturan farklı kesimlere ve tüm siyasi partilere eşit mesafede yayın gerçekleştirip gerçekleştirmediğini; belli kesimleri gerek çeşitli söylemler gerekse yok saymak sureti ile ötekileştirip ötekileştirmediğini bilimsel veriler ışığında saptamaktır. Çalışma medya ve siyaset ilişkisini kamusal yayıncılık bağlamında irdelemesi ve demokratik bir seçim sürecinde haber bültenlerinde farklı sivil toplum örgütlerinin\siyasi grupların kamusal arenada temsil sorununu bilimsel veriler ile ortaya koyması bakımından önem arz etmektedir.

\section{Yöntem ve Veri Toplama}

\subsection{Yöntem}

1 Nisan ve 15 Nisan 2017 tarihleri arasında yayınlanan TRT1 ana haber bültenlerinin incelendiği bu çalışmada içerik analizi yöntemi kullanılmıştır.

56112 sayılı Radyo ve Televizyonların Kuruluş ve Yayın Hizmetleri Hakkında Kanunun 8'inci maddesi'nin birinci fıkrasının (k) bendi. 
Araştırmada aşağıdaki sorulara cevap aranmıştır (Araştırma sorusu: AS):

AS1: 1- 15 Nisan tarihleri arasında yapılan hafta içi ana haber bültenlerinde yayınlanan haberlerin konusu, söylemi, süresi ve bülten içindeki sıralaması nasıl gerçekleşmiştir?

AS2:Yayınlanan referandum haberlerinde yer alan partiler, sivil toplum örgütleri nasıl temsil edilmiştir? Bu temsil ekseninde eleştirel ve muhalif düşünceye sahip grupların görüşlerine ne oranda yer verilmiştir?

AS3: Yayınlanan referandum haberlerinde yer alan partilerin (bu partiler 'evet' ve 'hayır' kararını desteklemeleri göz önüne alınarak iki ana gruba ayrılarak incelenmiştir) haber içinde temsil süreleri ve parti liderlerinin ekranda görünme süreleri hangi oranlarda gerçekleşmiştir?

AS4: Referandum haberlerinde haberin ana aktörü olan partilerin destekleyici detay görüntü kullanımı (miting görüntüsü, halk röportajları, ses efekt kullanımları vb.) iktidar ve muhalefet partilerinin haberlerinde değişiklik göstermekte midir?

\subsection{Veri Toplama}

İletişim araştırmalarında geçmişte yapılan içerik çözümlemelerinden hareketle örneklem konusunda bazı rehber ilkeler oluşturulmuştur. $\mathrm{Bu}$ tür araştırmalarda araştırmanın konusunu oluşturan evrenin hepsini incelmek çok zor ve bazen de imkânsız olduğu için araştırmanın evrenini temsilen örneklem olarak süreli haftalık yayın yapan dergilerin bir yıl içerisindeki 12 sayısının incelenmesi örneklemin evreni doğru ve güvenilir olarak temsili için yeterli görülmüştür. Aynı şekilde televizyon araştırmalarında ise incelenen konuya ve yayına göre örneklem olarak bütün bir haftanın veya toplamda dört haftanın alınması akademik çevrelerce yeterli görünmüştür (Geray, 2011: 159). Bu doğrultuda bu araştırmanın evrenini TRT1'de yayınlanan ana haber bültenleri oluşturmaktadır. Örneklem seçiminde ise hem güvenilirliği hem de doğruluğu arttırmak için iki haftalık bir periyod belirlenmiş ve 16 Nisan Anayasa Referandumu öncesindeki son iki hafta içerisinde yayınlanan 'Erhan Çelik ile TRT1 Ana Haber' bültenleri araştırmanın örneklemini oluşturmuştur. $\mathrm{Bu}$ iki haftalık periyod içerisinde toplamda 10 adet haber bülteni içerik analizi yöntemi ile incelenmiştir. Araştırma demokratik bir seçim sürecinde 
kamusal yayın organı olan TRT1 yayınlarında ötekileştirme yapıldığı varsayımından yola çıktığı için özellikle içerik analizi yöntemi ile incelenen haberlerin konusu referandum ile bağlantılı haberler olmuşsa da diğer haberlerdeki görünüm oranları da incelenmiştir. Hafta sonu haberlerinin daha fazla magazinsel içerik içermesi, meclis ve benzeri kamu kurumlarının hafta sonu tatili dolayısıyla kapalı olması ve referandum haberlerinin özelliklerinin yakalanamayacağı düşüncesinden hareketle hafta sonu haberleri örneklem dışı bırakılmıştır (Gökçe, 2006: 78).

İçerik analizi anlamlar üzerine odaklanmaktadır ve bu anlamları önceden belirlenen kategoriler aracılığı ölçmeyi hedeflemektedir (Gökçe, 2006: 63). Araştırmanın problemi çerçevesince belirlenen örneklem içerisinde değişkenlerin ölçülmesi, sınıflandırılması ve anlamlı bir sonuca ulaşılabilmek için bu doğrultuda kodlama cetveli oluşturulmuştur (Robson, 2015: 433). Öncelikle belirlenen tarihler arasındaki yayınlanan tüm haberler konusu ve süresi bakımından incelenmiştir. Konusu referandum ile ilgili haberler bülten içindeki sıralamalarına, bu haberlerde yer alan aktörlere (siyasetçi, bürokrat vb.) ve bu aktörlerin söylemlerine (eleştirel, bilgilendirici), liderlerin bu haberlerdeki konuşma sürelerine, temsil biçimlerine, aktörlerin ele alınış biçimlerine ve parti temsil oranlarına göre 7 ana kategori altında sınıflandırılmış ve incelenmiştir. Ayrıca televizyon haberlerinde kullanılan görüntülerin de ayrı bir anlam ifade ettiği, yazılı dili ve o dilin temsil ettiği ideolojiyi desteklemesi bakımında önem arz ettiği dikkate alınarak referandum haberleri görsel analize tabi tutulmuş ve bu başlık altında haberlerde temsil edilen partilerin veya liderlerin referandum haberlerinde miting görüntülerine ne kadar yer verildiği, slogan-alkış gibi efekt görüntülerinin kullanım oranları, miting görüntülerinin geniş açı çekim taktikleri ile daha kalabalık, etkili ve destekleyici gösteriminin nasıl ve ne oranlarda gerçekleştirildiği alt başlıklar olarak incelenmiş ve araştırmanın doğruluk ve güvenirliği arttırılmaya çalışılmıştır.

\section{Bulgular}


Bu çalışmada, 1 Nisan ve 15 Nisan 2017 tarihleri arasında TRT ekranlarında hafta içleri yayınlanan 'Erhan Çelik ile TRT1 Ana Haber' ${ }^{6}$ haber bültenleri araştırma kapsamında incelenmiştir. İncelenen bu on haberin toplam süresi 396 dakika (2.375 saniye), bir ana haber bülteninin ortalama süresi ise 40 dakika (2.375 saniye) olarak saptanmıştır. Ayrıca 1-15 Nisan tarihlerinde yayınlanan TRT1 ana haber bültenlerinde günlük haber sayısı en fazla 26, en az 20 olarak tespit edilirken, tüm günlerin toplamında 224 farklı haber izleyicilere aktarılmıştır. Bu haberlerin konularına göre tasnif ettiğimizde ise karşımıza şu bilgiler çıkmaktadır:

Tablo 1. 1-15 Nisan TRT1 Ana Haber Bültenlerinin Konuları ve Süreleri

\begin{tabular}{|c|c|c|c|c|c|c|c|c|c|c|c|c|c|c|c|c|}
\hline $\begin{array}{l}\text { Haberin } \\
\text { Konusu }\end{array}$ & 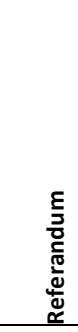 & 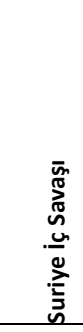 & 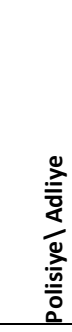 & 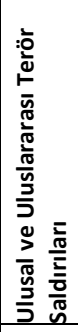 & 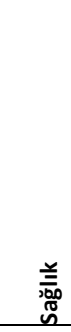 & 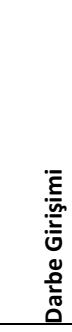 & 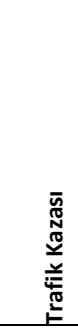 & 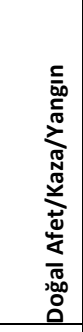 & 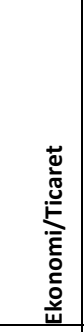 & 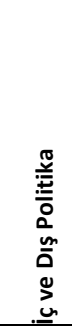 & 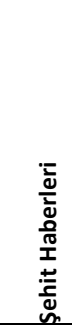 & 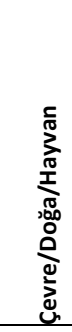 & 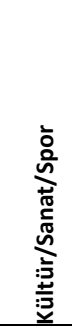 & 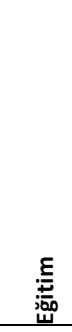 & 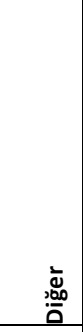 & $\begin{array}{l}\frac{\varepsilon}{\sigma} \\
\frac{0}{0} \\
\text { 을 }\end{array}$ \\
\hline $\begin{array}{l}\text { Haberin } \\
\text { süresi } \\
\text { (Dk.) }\end{array}$ & 77.1 & 54.45 & 37.03 & 29.96 & 32.2 & 31.99 & 20.39 & 19.21 & 23.42 & 9.13 & 9.72 & 7.4 & 9.56 & 5.1 & 29.27 & 395.93 \\
\hline $\begin{array}{l}\text { Haberin } \\
\text { oranı } \\
\text { (\%) }\end{array}$ & 20,09 & 12,05 & 9,82 & 8,48 & 8,48 & 6,25 & 5,8 & 5,8 & 5,36 & 3,13 & 2,68 & 1,79 & 1,79 & 1,34 & 7,14 & 100 \\
\hline $\begin{array}{l}\text { Haberin } \\
\text { Adedi }\end{array}$ & 45 & 27 & 22 & 19 & 19 & 14 & 13 & 13 & 12 & 7 & 6 & 4 & 4 & 3 & 16 & 224 \\
\hline
\end{tabular}

Tablo 1'e göre, 1-15 Nisan tarihleri içindeki TRT1 ana haber bültenlerinde en çok yer verilen konu toplamda 45 haber ile 16 Nisan 2017'deki anayasa değişikliği referandumudur. Ayrıca Referandum haberlerinin süresi de diğer haber sürelerinin üzerindedir. Tablodaki verilere göre toplam Referandum haber süresi 77 dakika ile ilk sırada gelmektedir. Ardından sırasıyla 54 dakika ile Suriye İç Savaşı, 37 dakika ile Polisiye/Adliye, 30 dakika ile Ulusal ve Uluslararası Terör Saldırıları haberleri gelmektedir.

\footnotetext{
${ }^{6}$ Haber tarihlerinin günleri: 3 Nisan, 4 Nisan, 5 Nisan, 6 Nisan, 7 Nisan, 10 Nisan, 11 Nisan, 12 Nisan, 13 Nisan, 14 Nisan.
} 


\section{Şekil 1. 1-15 Nisan Tarihlerinde TRT1 Ana Haber Bültenlerinin ‘Haber’ Konu}

\section{Dağılımı}

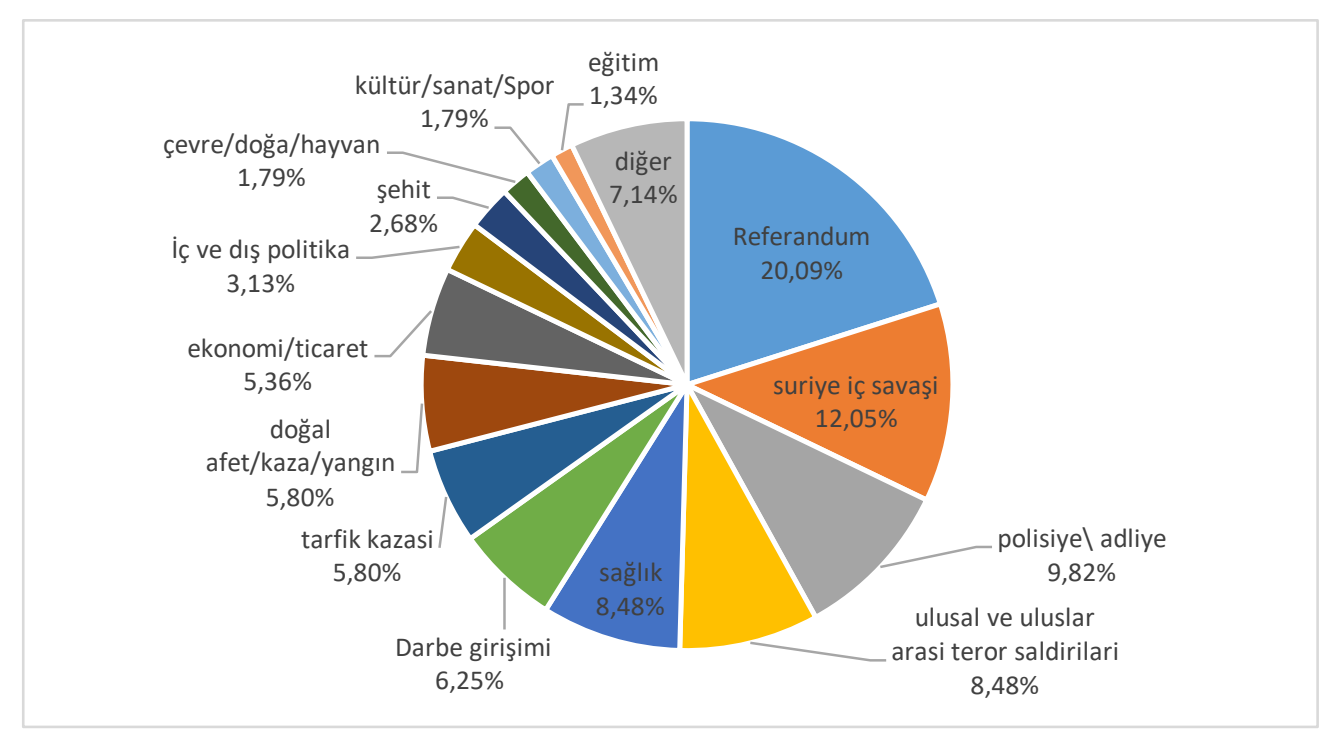

Şekil 1'de de görüldüğü üzere TRT1 ana haber bültenlerindeki Referandum haberleri yüzde 20 ile haber konuları arasında en fazla payı almaktadır. Ardından yüzde 12 ile Suriye Iç Savaşı, yüzde 10 ile Polisiye/Adliye, yüzde 8 Ulusal ve Uluslararası Terör Saldırlları haberleri gelmektedir.

Tablo 1 ve Şekil 1'deki veriler, TRT'nin diğer haberlere kıyasla Referandum haberlerine daha fazla önem verdiğini göstermektedir. Tablo 1 ve Şekil 1'deki verileri daha kapsamlı analiz edebilmek için araştırma iki farklı şekilde incelenmiştir. Buna göre ilk olarak, TRT1 ana haber bültenlerinde yayınlanan sadece Referandum haberlerinin analizi yapılmış, daha sonra ise yayınlanan tüm haberler mercek altına alınmıştır. Böylelikle TRT'nin özellikle önem verdiği anlaşılan Referandum haberlerini izleyiciye sunma ve aktarma yaklaşımı karşılaştırmalı olarak ortaya konmuştur.

\subsection{1-15 Nisan Tarihlerinde TRT1 Ana Haber Bültenlerinde Yayımlanan Referandum Haberleri ve Bu Referandum Haberlerinin Analizi}

Araştırma tarihleri içerisinde TRT1 ana haber bültenlerinde 77 dakika ile en fazla süre verilen (Tablo 1) ve yüzde 20 pay oranı ile en fazla konusu geçen (Şekil 1) Referandum haberlerinin haber bültenlerindeki sıralamasını şu şekildedir: 


\section{Şekil 2. 1-15 Nisan Tarihlerinde TRT1 Ana Haber Bültenlerinin 'Referandum' Haberlerinin Öncelik Sıralamaları}

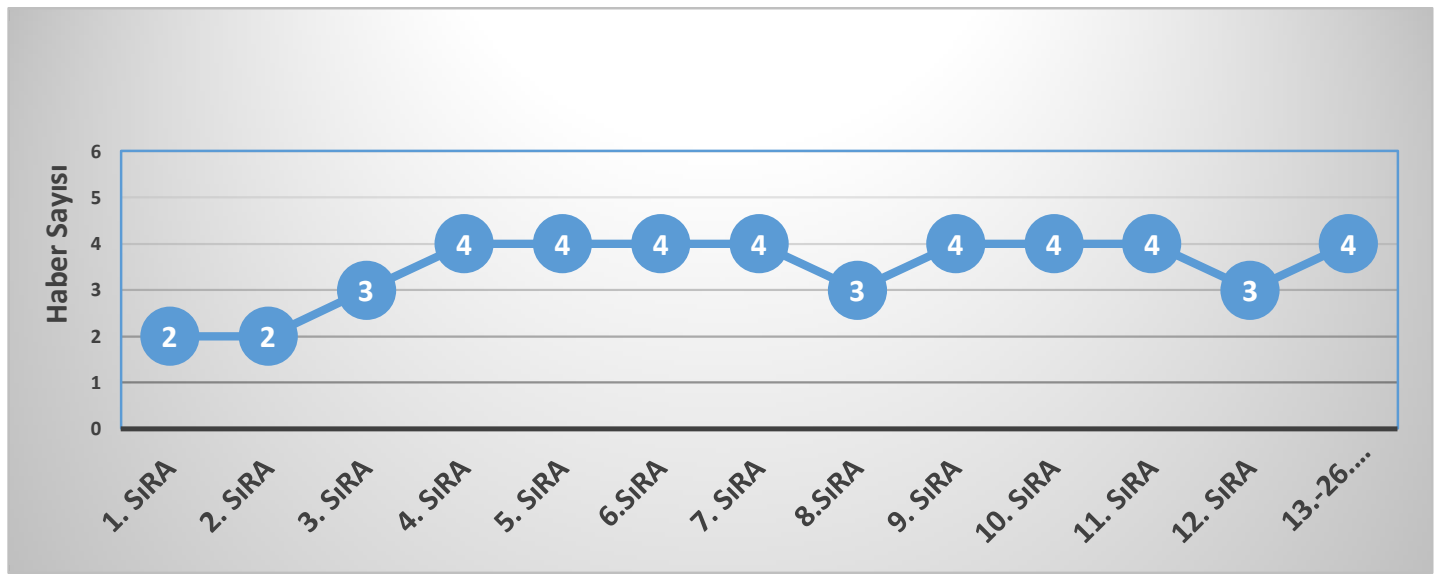

1-15 Nisan tarihlerindeki TRT1 Ana Haber bültenlerinde toplam 224 haberin

45'i Referandum haberlerine ayrılmıştır (tablo 1). Bu 45 Referandum haberinin Şekil 2'ye göre 34'ü ilk 10 haber arasında yer almıştır. Geriye kalan toplam 11 Referandum haberi ise 11. ve sonraki haber sıralamalarında yer almıştır. Bu bilgiler 1şığında TRT1 ana haberde yayınlanan Referandum haberlerinin yüzde 76'sına ilk 10 haber arasında yer verilmiştir. Aşağıdaki şekilde söz konusu bu durum ortaya konulmuştur.

Şekil 3. 1-15 Nisan Tarihlerindeki TRT1 Ana Haber Bültenlerinde Yayınlanan 'Referandum' Haberlerinin Haber Öncelik Sıralaması

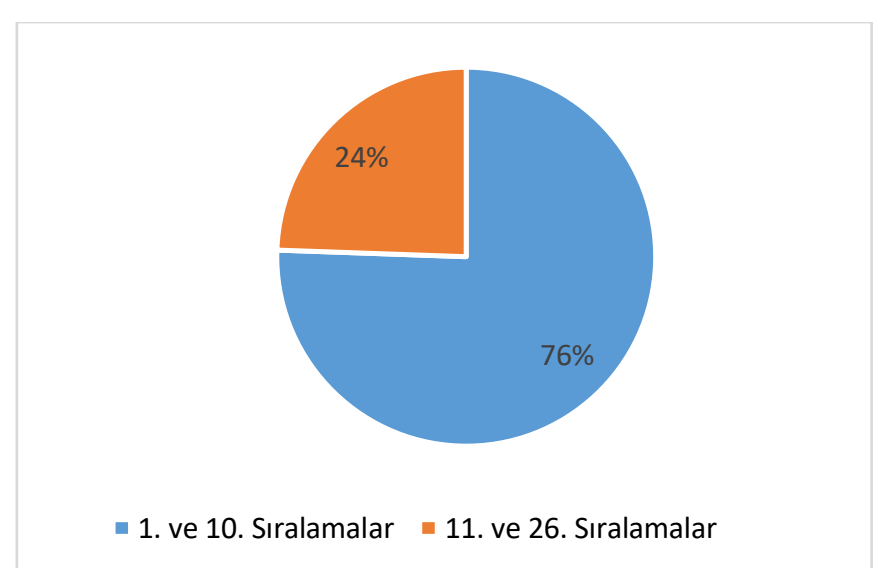

Şekil 2 ve 3'deki veriler TRT'nin '16 Nisan Anayasa Referandumu' konusuna verdiği önceliği açık bir biçimde ortaya koymaktadır. Buna göre bir devlet kanalı olarak TRT'nin özellikle önem verdiği anlaşılan '16 Nisan Anayasa Referandumu'na yaklaşım tarzının açığa kavuşturulması daha çok önemli hale 
gelmiştir. Bu bağlamda araştırma tarihleri içerisindeki TRT1 ana haber bültenlerinde yayınlanan Referandum haberlerinin içerik analizi yapılmış ve aşağıdaki veriler ortaya çıkmıştır:

Tablo 2. 1-15 Nisan Tarihlerindeki TRT1 Ana Haber Bültenlerinde Yayınlanan Referandum Haberlerinin İçeriği

\begin{tabular}{|c|c|c|c|c|c|c|c|c|}
\hline Haber & \multicolumn{5}{|c|}{ Haberin Aktörü } & \multicolumn{3}{c|}{ Haberin Söylemi } \\
\hline Referandum & Siyasetçi & Bürokrat & Sivil & Asker/Polis & Diğer & Bilgilendirici & Eleştirel & Diğer \\
\hline 45 & 38 & 2 & 3 & 2 & 2 & 43 & 2 & 1 \\
\hline Payı & 80,85 & 4,26 & 6,38 & 4,26 & 4,25 & 93,48 & 4,35 & 2,17 \\
\hline
\end{tabular}

Tablo 2'ye göre yayınlanan toplam 45 Referandum haberinin 38'i 'siyasetçi' ler üzerinden haberleştirilmiştir. Haberin söyleminde ise yüzde 94 oranıyla 'bilgilendirici' bir yol izlenmiştir. Buna göre TRT1 ana haber bültenleri Referandum haberlerini yüzde 81 oranıyla 'siyasetçi aktörler' üzerinden izleyicilere 'bilgilendirici' bir şekilde sunmuştur. Siviller, sivil toplum örgütleri, sivil toplum kuruluşları, dernekler, vakıflar, akademisyenler, iş adamları, bağımsız kurum ve kuruluşlar gibi aktörler ise sadece 5 referandum haberinde yer almıştır. Referandum haberlerini yüzde 89,37 oranında siyasetçi, bürokrat, asker ve polislerden oluşan devlet görevlileri ve yetkililerinin söylemlerinden alımlanmıştır. Bu bağlamda haberlerin ağırlıklı olarak hangi siyasetçi aktörler tarafından izleyicilere sunulduğu, TRT1'in Referandum haberlerine yaklaşımını ortaya koyması bakımından önemlidir.

Tablo 3. 1-15 Nisan Tarihlerindeki TRT1 Ana Haber Bültenlerinde Yayınlanan Referandum Haberlerinde Siyasetçi Görünümü

\begin{tabular}{|l|l|l|l|c|c|c|c|c|c|}
\hline \multicolumn{10}{|c|}{ Referandum Haberlerinde Görünüm } \\
\hline & $\begin{array}{l}\text { R. } \\
\text { Tayyip } \\
\text { Erdoğan }\end{array}$ & $\begin{array}{l}\text { Binali } \\
\text { Yıldırım }\end{array}$ & $\begin{array}{l}\text { Kemal } \\
\text { Kilıçdaroğlu }\end{array}$ & $\begin{array}{l}\text { Devlet } \\
\text { Bahçeli }\end{array}$ & $\begin{array}{l}\text { Temel } \\
\text { Karamollaoğlu }\end{array}$ & $\begin{array}{l}\text { AK Parti'li } \\
\text { Bakan ve } \\
\text { Milletvekilleri }\end{array}$ & $\begin{array}{l}\text { CHP'li } \\
\text { Milletvekilleri }\end{array}$ & $\begin{array}{l}\text { MHP'li } \\
\text { Milletvekilleri }\end{array}$ & $\begin{array}{l}\text { Diğer } \\
\text { Partiler }\end{array}$ \\
\hline Görünüm & 15 & 12 & 14 & 3 & 1 & 9 & 2 & 1 & 0 \\
\hline $\begin{array}{l}\text { Referandum } \\
\text { Kararı }\end{array}$ & Evet & Evet & Hayır & Evet & Hayır & Evet & Hayır & Evet & - \\
\hline
\end{tabular}

Tablo 3'e göre yayınlanan 45 Referandum haberinin 15'inde görünümü yer alan Cumhurbaşkanı R. Tayyip Erdoğan, Referandum haberinde en fazla görünen 
siyasetçidir. Ardından sırasıyla 14 kere CHP Genel Başkanı Kemal Kılıçdaroğlu, 12 kere Başbakan Binali Yıldırım, 3 kere MHP Genel Başkanı Devlet Bahçeli, 1 kere de Saadet Partisi Genel Başkanı Temel Karamollaoğlu haberlerde görüntülenmiştir (eleştirildiği anda ekranda gözükmüşsür). Ayrıca Referandum haberinde partili milletvekillerinin görünümleri de dikkat çekmektedir. Buna göre Referandum haberlerinde AK Parti'li Bakan ve milletvekilleri 9 kez görüntülenmişken, CHP'li milletvekilleri 2, MHP'li milletvekilleri 1 kere görüntülenmiştir. Referandum haberinde gösterilen parti liderleri ve milletvekillerinin Referandum öncesi almış olduğu 'evet/hayır' parti kararlarına göre görünüm dağılımı şu şekildedir:

\section{Şekil 4. 1-15 Nisan Tarihlerindeki TRT1 Ana Haber Bültenlerinde Yayınlanan Referandum Haberlerinde 'Görünümü’ Yer Alan Partili Milletvekillerinin Evet/Hayır Dağılımı?}

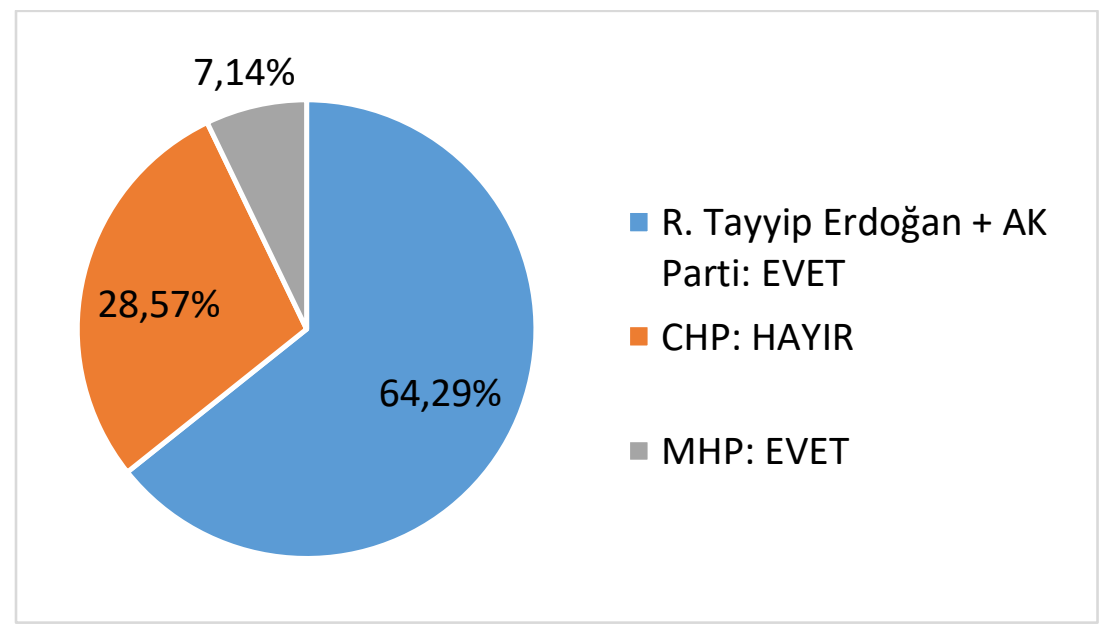

Şekil 4'e göre, TRT1 Ana Haber bültenlerinde yayınlanan Referandum haberlerinde yüzde 64,29 oranında Cumhurbaşkanı Recep Tayyip Erdoğan, AK Parti Genel Başkanı Binali Yıldırım, AKP'li bakan ve milletvekillerinin görüntüleri kullanılmışken ${ }^{8}$; yüzde 28,57 ile CHP Genel Başkanı Kemal Kılıçdaroğlu ve CHP'li milletvekilleri; yüzde 7,14 ile MHP Genel Başkanı Devlet Bahçeli ve MHP'li

\footnotetext{
${ }^{7}$ Şekil 4, tablo 3'deki verilerden oluşturulmuştur ama bu grafiğe Saadet Partisi Genel Başkanı Temel Karamollaoğlu'nun 1 olan görünüm sayısı eklenmemiştir. Bunun nedeni söz konusu haberde Saadet Partisi'nin temsili yapılmamış, aksine olumsuz anlamda yapılan eleştirel bir söylemde kullanılmış olmasıdır.

${ }^{8}$ Referandum öncesi Cumhurbaşkanı R. Tayyip Erdoğan'ın hem eski AK Parti Genel Başkanı olması hem de Referandum da Partili Cumhurbaşkanlığını desteklemesi nedeniyle araştırma boyunca AK Parti ile birlikte değerlendirilmiştir.
} 
milletvekillerinin görüntüsü kullanılmıştır. Bu bilgilere göre sadece görünüm olarak Referandum haberlerinde yer alan siyasilerin 16 Nisan Anayasa Referandumu'nda Evet/Hayır oy kararlarına göre dağılımı yüzde 71 'Evet', yüzde 29 'Hayır' olarak saptanmıştır. ${ }^{9}$ Dolayısıyla TRT1 ana haber bültenlerinin Referandum haberlerinde 'Evet' kararı veren siyasilere daha çok yer verilmiştir.

Tablo 4. 1-15 Nisan Tarihlerindeki TRT1 Ana Haber Bültenlerinde Yayınlanan Referandum Haberlerinde Siyasi Liderlerin Konuşma Süreleri

\begin{tabular}{|l|c|c|c|c|c|}
\hline \multicolumn{7}{|c|}{ Referandum Haberlerinde Liderlerin Konuşma Süresi } \\
\hline & R. Tayyip Erdoğan & Binali Yıldırım & Kemal Kılıçdaroğlu & $\begin{array}{l}\text { Devlet } \\
\text { Bahçeli }\end{array}$ & Diğer \\
\hline Konuşma Görünümü & 14 & 11 & 8 & 3 & 0 \\
\hline Konuşma Süresi(dk) & 16.28 & 13.81 & 6.58 & 2.15 & 0 \\
\hline Referandum Kararı & Evet & Evet & Hayır & Evet & - \\
\hline
\end{tabular}

Tablo 4'e göre Referandum haberlerinde en fazla konuşma süresi 16,28 dakika ile Cumhurbaşkanı Recep Tayyip Erdoğan'a ayrılmıştır. Ardından sırasıyla 13,81 dakika ile Başbakan ve AK Parti Genel Başkanı Binali Yıldırım, 6,58 dakika ile CHP Genel Başkanı Kemal Kılıçdaroğlu, 2,15 dakika ile MHP Genel Başkanı Devlet Bahçeli'nin Referandum haberlerinde konuşmalı görüntüleri yer almıştır. Tablo 4'de de görüldüğü gibi Referandum haberlerinin hiçbirinde diğer parti liderlerinin konuşmasına yer verilmemiştir. Konuşmalı görüntülerine yer verilen bu siyasi parti liderlerinin referandumdaki siyasi kararlarına baktığımızda ise 'Evet' diyen siyasetçilere ayrılan toplam sürenin 32,24 dakika, 'Hayır' diyen siyasetçilere ayrılan toplam sürenin ise 6,58 dakika olduğu görülmektedir.

1-15 Nisan tarihlerindeki TRT1 Ana Haber Bültenlerinde Yayınlanan Referandum Haberlerinde Konuşma Süresi Alan Siyasi Parti Liderlerinin Parti Temsilleri ve Referandum Kararları şöyledir:

\footnotetext{
${ }^{9}$ Referandum haberlerinde özellikle 'Evet' oyu kullanacak siyasi liderlerin 'Hayır' oyu kullanacak parti veya liderlerini eleştirdiği anda görüntülenmesi dikkat çekmiştir. Örneğin, Cumhurbaşkanı R. Tayyip Erdoğan'ın 'Hayır' oyu kullanma kararı almış olan Saadet Partisi'ni eleştirirken Temel Karamollaoğlu'nun görüntüsünün ekrana yansıması.
} 


\section{Şekil 5. Referandum Haberlerinde Konuşma Süresine Göre Siyasi Liderlerin Parti} Temsilleri

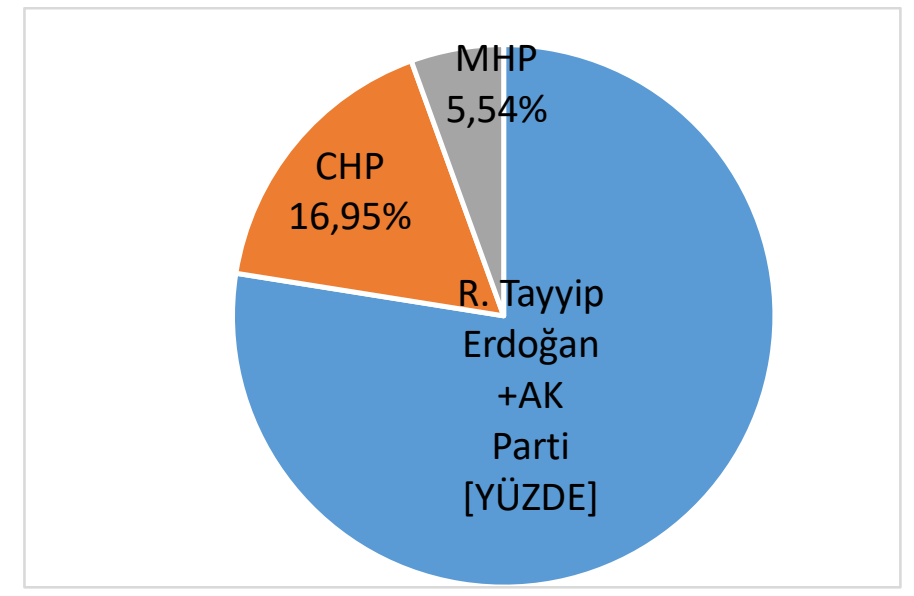

\section{Şekil 6- Referandum Haberlerinde 'Evet/Hayır' Karar Oranları}

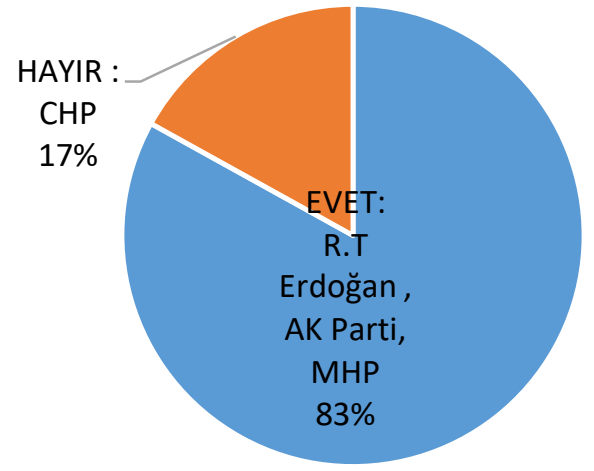

Şekil 5 ve 6'ya göre Referandum haberlerinde liderlerin parti temsilleri üzerinden en fazla konuşma süresi yüzde 77,51 payı ile Cumhurbaşkanı Recep Tayyip Erdoğan ve AK Partiye ayrılmıştır. Ardından yüzde 16,95 ile CHP, yüzde 5,54 ile MHP gelmektedir. $\mathrm{Bu}$ siyasi liderlerin referandumdaki kararlarına baktığımızda ise 'Evet'çilere ayrılan toplam sürenin yüzde 83 (32.24 dk.), 'Hayır'cılara ayrılan toplam sürenin yüzde 17 (6.58 dk.) olduğu tespit edilmiştir. 


\section{Tablo 5. 1-15 Nisan Tarihlerindeki TRT1 Ana Haber Bültenlerinde Yayınlanan Referandum Haberlerin Sunumu}

\begin{tabular}{|c|c|c|c|c|c|c|c|c|c|c|c|c|}
\hline \multicolumn{13}{|c|}{ Referandum Haberlerinde } \\
\hline & \multicolumn{2}{|c|}{$\begin{array}{c}\text { Temsil } \\
\text { Edilen Parti }\end{array}$} & \multicolumn{2}{|c|}{ Ana Aktör } & \multirow{2}{*}{$\begin{array}{c}\text { Temsil Edilen } \\
\text { Partinin veya } \\
\text { Liderinin } \\
\text { Doğrudan } \\
\text { Kullanımı } \\
\text { Sayı }\end{array}$} & \multirow{2}{*}{\begin{tabular}{|c|} 
Temsil \\
Edilen \\
Partinin veya \\
Liderinin \\
Dolaylı \\
Olarak \\
Kullanımı \\
Sayı
\end{tabular}} & \multirow{2}{*}{$\begin{array}{c}\text { Destekleyici } \\
\text { Detay } \\
\text { Görüntü } \\
\text { Kullanımı } \\
\\
\text { Sayı }\end{array}$} & \multirow{2}{*}{$\begin{array}{c}\text { Basit } \\
\begin{array}{c}\text { Görüntü } \\
\text { Kullanımı }\end{array} \\
\text { Sayı }\end{array}$} & \multirow{2}{*}{$\begin{array}{c}\text { Miting } \\
\text { Detay } \\
\text { Kullanımları } \\
\text { Sayı }\end{array}$} & \multirow{2}{*}{$\begin{array}{c}\text { Geniş Açı } \\
\text { Çekim } \\
\text { Tekniğinin } \\
\text { Kullanımı } \\
\\
\text { Sayı }\end{array}$} & \multirow{2}{*}{$\begin{array}{c}\text { Slogan, } \\
\text { Alkış vb. } \\
\text { Efekt } \\
\text { Sesleri } \\
\text { Sayı }\end{array}$} & \multirow{2}{*}{ 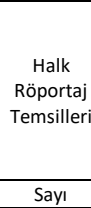 } \\
\hline Parti & Sayı & Dk. & Sayı & Dk. & & & & & & & & \\
\hline AK Parti & 21 & 38.45 & 21 & 38.86 & 23 & 0 & 22 & 0 & 20 & 20 & 17 & 7 \\
\hline $\mathrm{CHP}$ & 15 & 21.7 & 9 & 11.53 & 7 & 9 & 3 & 14 & 2 & 1 & 0 & 1 \\
\hline MHP & 3 & 4.65 & 2 & 2.56 & 3 & 2 & 1 & 3 & 1 & 0 & 0 & 0 \\
\hline SAADET P. & 0 & 0 & 0 & 0 & 0 & 1 & 0 & 0 & 0 & 0 & 0 & 0 \\
\hline Diğer Partiler & 0 & 0 & 0 & 0 & 0 & 0 & 0 & 0 & 0 & 0 & 0 & 0 \\
\hline Toplam & 39 & 64.8 & 32 & 52.95 & 33 & 12 & 26 & 17 & 23 & 21 & 17 & 8 \\
\hline
\end{tabular}

Tablo 5'e göre 1-15 Nisan tarihlerindeki TRT1 ana haber bültenlerinde yaymlanan Referandum haberlerinde AK Parti 38,45 dakika ile en fazla temsil edilen parti olmuştur. İkinci sırada 21,7 dakika ile CHP, üçüncü sırada 4,65 dakika ile MHP yer alır. Referandum haberlerinin ana aktörlerine baktığımızda ise AK Parti yine ilk sirada gelmektedir. 38,86 dakika ile Referandum haberlerinde ana aktör olan AK Parti’yi, 11,53 dakika ile CHP takip etmektedir. CHP, 9 kez Referandum haberlerinin ana aktörü olmuştur. MHP ise toplamda 2,56 dakika ile sadece iki haberde ana aktör konumundadır.

Tablo 5'e göre Referandum haberlerinde temsil edilen partinin veya liderinin doğrudan kullanımında (haberin konusu olan liderin konuşma esnasında görüntüsünün ekrana direk yansıması ve sözlerinin birinci ağızdan izleyiciye ulaşması). AK Parti 23, CHP 7, MHP 3 haberde sunulmuşken; temsil edilen partinin veya liderinin dolaylı kullanımında (haber içinde konuşma görüntüsünün hiç verilmemesi veya çok az verilmesi, sözlerinin spiker veya muhabir gibi üçüncü kişiler tarafından aktarılması). AK Parti hiç sunulmamıştır. Dolaylı anlatımla en fazla

\footnotetext{
${ }^{10}$ Basit görüntü kullanımı, haber kurgusunda haberi destekleyen ek görüntü ve seslerin (efekt, müzik vb.) kullanılmamasıdır. Bazı haberlerde ana aktörü daha etkin gösterebilmek için sinematografik bir dil kullanıııken (miting alanını daha coşkulu ve kalabalık göstermek, geniş açılar kullanmak, yüceltici alt açılar kullanmak, alkış sesleri vermek, haraketli kamera kullanmak vb.) ve bu görüntüler ses efektleri (alkış vb.) ile desteklenirken basit görüntü kullanımı yapılan haberlerde bu tür özelliklere yer verilmemiştir.

Not: Bu başlık araştırmanın ilk aşamasında planlanan kodlama cetvelinde yer almamaktaydı. Fakat seçilen örneklemin analizleri için haber görüntüleri biz araştırmacılar tarafından izlenmeye başlandığında referandum haberlerinde kullanılan görsel dilin partilere göre farklılık gösterdiği saptanmış ve bu sebepten dolayı bu başlık tabloya eklenmiştir.
} 
sunulan parti ise $9 \mathrm{kez}$ konusu geçen CHP'dir. MHP'de 2 kere dolaysız anlatım ile haberlerde yer almıştır. Tabloda dikkat çekici sonuç ise Temsil Edilen Parti ve Ana Aktör konumunda hiç haberi yapılmayan Saadet Partisi'nin ismi ve partinin Genel Başkanı Temel Karamollaoğlu'nun görüntüsü, eleştirel bir söylemin yapıldığı bir haberde kullanılmış olmasıdır. Böylelikle Saadet Partisi, Temsil Edilen Partinin veya Liderinin Dolaylı Olarak Kullanımına olumsuz olarak bir kere konu olmuştur.

Tablo 5'deki verilere göre, AK Parti haberi sunumlarının görsel olarak daha fazla detaya sahip olduğu görülmektedir. Buna göre AK Parti'nin tüm haberleri destekleyici görsellerle sunulmuş, basit görüntü kullanımından kaçınılmıştır. CHP haberlerine baktığımızda ise 3 haberde destekleyici görüntüler kullanılırken, 14 haberinde içerikler basit görüntüler ile izleyiciye aktarılmıştır. MHP'de de sadece 1 haber detaylı görüntülerle servis edilmiş, 3 haberinde ise basit görüntü kullanımına gidilmiştir. $\mathrm{Bu}$ verileri destekleyecek bir diğer inceleme de parti mitinglerinin haberlere yansıma biçimidir. Buna göre AK Parti haberlerinin 20'sinde AK Parti mitinglerinin detaylı görüntüleri kullanılmıştır. CHP'nin 2, MHP'nin ise 1 haberinde bu partilerin miting görüntüleri haber görsellerinde yer almıştır.

TRT1 ana haber bültenlerinde Referandum haberlerinin görselliğini zenginleştirmek ve etkisini artırmak için iki yöntem kullanılmıştır. Bunlardan birincisi haber görsellerinde geniş açı lens kullanımı, ikincisi ise ses, slogan ve benzeri ses efektlerinin kullanımlarıdır. Buna göre AK Parti haberlerinin 20'sinde geniş açılı görüntüler, 17'sinde de ses, slogan gibi efekt seslerinden yararlanılmıştır. Böylelikle AK Parti haberlerinde kitlesel zenginlik ve coşkunluk hissi yansıtılmıştır. CHP ve MHP haberlerinde ise geniş açı kullanımına gidilmemiş, CHP'nin sadece bir haberinde ses, slogan gibi efekt seslerinden yararlanılmıştır. Böylelikle TRT'nin seçmenin kararlarını etkileme yönündeki potansiyeli açığa kavuşturulmuştur. Ayrıca araştırma tarihleri içinde Tablo 5'deki siyasi partiler haricinde başka bir parti haberlerine rastlanılmamış olması da dikkat çekici bir veri olarak ortaya çıkmıştır. 


\subsection{1-15 Nisan Tarihlerindeki TRT1 Ana Haber Bültenlerinde Yayınlanan Tüm Haberlerin Sunumu Ve Analizleri}

Tablo 6. 1-15 Nisan Tarihlerindeki TRT1 Ana Haber Bültenlerinde Yayınlanan Haberlerin Sunumu

\begin{tabular}{|c|c|c|c|c|c|c|c|c|c|c|c|c|}
\hline \multicolumn{13}{|c|}{ Tüm Haberlerde } \\
\hline & $\begin{array}{l}\text { Temsil } \\
\text { Parti }\end{array}$ & Edilen & Ana Ak & & $\begin{array}{l}\text { Temsil } \\
\text { Edilen } \\
\text { Partinin } \\
\text { veya } \\
\text { Liderinin } \\
\text { Doğrudan } \\
\text { Kullanımı }\end{array}$ & \begin{tabular}{|l} 
Temsil \\
Edilen \\
Partinin \\
veya \\
Liderinin \\
Dolaylı \\
Olarak \\
Kullanımı
\end{tabular} & $\begin{array}{l}\text { Destekleyici } \\
\text { Detay } \\
\text { Görüntü } \\
\text { Kullanımı }\end{array}$ & $\begin{array}{l}\text { Basit } \\
\text { Görüntü } \\
\text { Kullanımı }\end{array}$ & $\begin{array}{l}\text { Miting Detay } \\
\text { Kullanımları }\end{array}$ & $\begin{array}{l}\text { Geniş Açı } \\
\text { Lens } \\
\text { Kullanımı }\end{array}$ & $\begin{array}{l}\text { Slogan, } \\
\text { Alkış } \\
\text { vb. } \\
\text { Efekt } \\
\text { Sesleri }\end{array}$ & $\begin{array}{l}\text { Halk } \\
\text { Röportaj } \\
\text { Temsilleri }\end{array}$ \\
\hline Parti & Adet & Dk. & Adet & Dk. & Adet & Adet & Adet & Adet & Adet & Adet & Adet & Adet \\
\hline AKP & 25 & 52.3 & 21 & 43.86 & 27 & 2 & 27 & 0 & 25 & 25 & 18 & 8 \\
\hline $\mathrm{CHP}$ & 16 & 22.45 & 10 & 12.28 & 7 & 10 & 3 & 16 & 2 & 1 & 0 & 1 \\
\hline HDP & 0 & 0 & 0 & 0 & 0 & 0 & 0 & 0 & 0 & 0 & 0 & 0 \\
\hline MHP & 3 & 4.65 & 2 & 2.56 & 3 & 2 & 1 & 4 & 1 & 1 & 0 & 0 \\
\hline SAADET & 0 & 0 & 0 & 0 & 0 & 2 & 0 & 0 & 0 & 0 & 0 & 0 \\
\hline Diğer & 0 & 0 & 0 & 0 & 0 & 0 & 0 & 0 & 0 & 0 & 0 & 0 \\
\hline Toplam & 44 & 79.4 & 34 & 58.7 & 37 & 15 & 31 & 20 & 28 & 27 & 18 & 9 \\
\hline
\end{tabular}

Tablo 6'ya göre TRT1 ana haber bültenlerinde yer alan tüm haberlerde en fazla AK Parti temsil edilmiş ve 52,3 dakika ile en fazla AK Parti haberlerine süre ayrılmıştır. CHP temsil edilen partiler arasında ikinci sıradadır. CHP’ye ayrılan süre 22.45 dakikadır. AK Parti'ye ayrılan süre CHP'ye ayrılan sürenin iki katından fazladır. MHP ise sadece 3 haberde temsil edilmiş ve 4,65 dakika süre ayrılmıştır. Tablo 6'daki verilere göre TRT1'nin tüm haberlerinde ana aktör konumunda olan parti de AK Parti'dir. 21 haberde ana aktör olan AK Parti'ye haberlerde ayrilan toplam süre 48.86 dakikadır. CHP 12,28 dakika ile 10 haberde ana aktör konumundadır. MHP ise toplam 2,56 dakika ile sadece 2 haberde ana aktör konumunda yer almıştır. TRT1 ana haber bültenlerinde toplam süresi 58,7 dakika olan siyaset haberlerinin ana aktörü 43,86 dakika ile AK Parti'dir. Bu durum TRT1 ana haber bültenlerindeki siyaset haberlerinin yüzde 75'inin AK Parti'ye ayrıldığını göstermektedir. Geri kalan siyaset haberlerinin yüzde 21 CHP'ye, yaklaşık yüzde 5'i de MHP'ye ayrılmıştır. Diğer siyasi partilere ise haberlerde hiç süre verilmediği tespit edilmiştir. Aşağıda yer alan Şekil 7'deki veriler bu durumu ortaya koymaktadır: 


\section{Şekil 7. 1-15 Nisan Tarihleri Trt1 Ana Haber Bültenlerinde Ana Aktör Konumundaki} Partilerin Süre Dağılımı

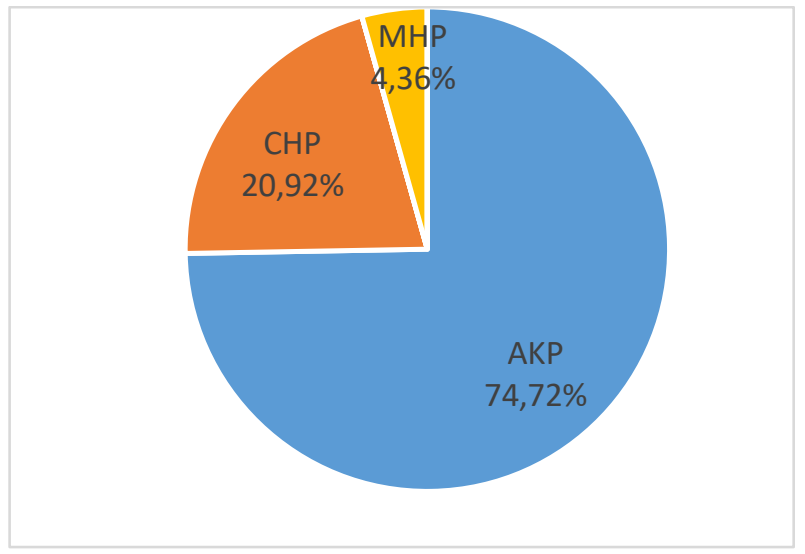

Tablo 6'daki verilere göre, 1-15 Nisan tarihlerindeki TRT1 ana haber bültenlerinde yer alan tüm haberlerde temsil edilen partinin veya liderinin doğrudan kullanımında 27 kere AK Parti'nin temsil edildiğini görülmektedir. CHP’nin 7, MHP'nin ise 3 haberde partisinin veya liderinin doğrudan kullanımı söz konusudur. $\mathrm{Bu}$ haberlerdeki temsil edilen partinin veya liderinin dolaylı kullanımında ise CHP 10 kere temsil edilmişken, AK Parti ve MHP 2 kere temsil edilmiştir. Dolayısıyla AK Parti haberlerde çoğunlukla doğrudan kullanılmışken, siyasi rakipleri ise dolaylı bir anlatımla sunulmuştur. Ayrıca tablo 6'ya göre basit görüntü kullanımının olmadığı 27 AK Parti haberi, detaylı görüntülerle zenginleştirilmiş, bu haberlerin 25'inde miting görüntüleri yer almış ve bu haberler geniş açılı görüntülerle sunulmuştur. 18 AK Parti haberinde slogan, alkış ve benzeri seslerle haberler desteklenmiş, parti görüşünü destekleyici 8 sivil kişi ile röportaj yapılmıştır. CHP'nin haberlerinin sadece üçü detaylı görüntü kullanımı ile zenginleştirilmiş, 16 haberinde ise basit kurgusal görüntülerle haberler sunulmuştur. CHP'nin iki haberinde parti mitinglerinden detaylar gösterilmişken, bu iki haberin birinde geniş açılı görüntüler kullanılmış ama iki haberde de haberi destekleyecek slogan, alkış ve benzeri sesler kullanılmamıştır. CHP'nin görüşlerini destekleyen bir sivil kişi ile yapılan röportaj haberin birinde yer almıştır. MHP'nin sadece bir haberi detay görüntüler ile zenginleştirilmiştir, dört haberi ise basit bir kurgusal tarzda sunulmuştur. MHP haberlerinin sadece birinde partinin mitinglerinden görüntüler eklenmiş ve geniş açılı görüntülerin olduğu bir haber sunulmuştur. Ayrıca MHP 
haberlerinde slogan, alkış ve benzeri ses efektleri kullanılmamış, sivillerle yapılan röportajlarda parti görüşünü destekleyici hiç kimseye yer verilmemiştir.

Tablo 7. 1-15 Nisan Tarihlerinde TRT1 Ana Haber Bültenlerinde Yayınlanan Tüm Haberlerde Siyasi Lider Görünümü Ve Konuşma Süreleri

\begin{tabular}{|l|c|c|c|c|c|c|}
\hline \multicolumn{7}{|c|}{ Tüm Haberlerde } \\
\hline & $\begin{array}{c}\text { R. Tayyip } \\
\text { Erdoğan }\end{array}$ & $\begin{array}{c}\text { Binali } \\
\text { Yıldıım }\end{array}$ & $\begin{array}{c}\text { Kemal } \\
\text { Kılıçdaroğlu }\end{array}$ & $\begin{array}{c}\text { Devlet } \\
\text { Bahçeli }\end{array}$ & $\begin{array}{c}\text { Temel } \\
\text { Karamollaoğlu }\end{array}$ & Diğer \\
\hline Görünüm Sayısı & 36 & 15 & 17 & 4 & 1 & 0 \\
\hline Konuşma Süresi & 24,16 & 14,83 & 7,16 & 2,31 & 0 & 0 \\
\hline
\end{tabular}

Tablo 7'e göre TRT ana haber bültenlerindeki tüm haberlerde Cumhurbaşkanı Recep Tayip Erdoğan, 36 görünüm sayısı ve 24,16 dakika konuşma süresi ile en fazla gösterilen ve konuşma süresi ayrılan olan siyasetçidir. Başbakan Binali Yıldırım toplamda $15 \mathrm{kez}$ görünüm ve 14,83 dakika konuşma süresi ile haberde yer almıştır. CHP Genel Başkanı Kemal Kılıçdaroğlu 17 kez görünüm, 7,16 dakika konuşma süresi elde ederken, MHP Genel Başkanı Devlet Bahçeli 4 kez görünüm ve 2,31 dakika konuşma süresi ile haberlerde yer almıştır. Temel Karamollaoğlu ise 1 kere eleştirilen bir haberde görüntülenmiş ama konuşmasına yer verilmemiştir. $\mathrm{Bu}$ bilgilere göre liderlerin haberlerde konuşma süresi payları şu şekilde oluşmuştur:

\section{Şekil 8. 1-15 Nisan Tarihlerinde TRT1 Ana Haber Bültenlerinde Yer Alan Tüm Haberlerde Siyasi Liderlere Ayrılan Konuşma Süreleri}

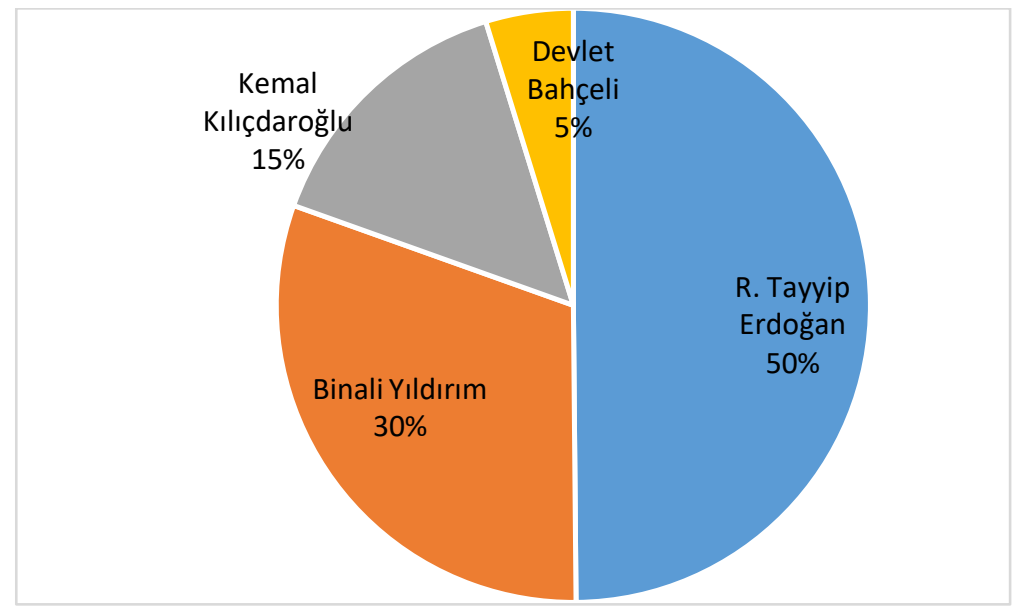

Şekil 8'deki bilgilere göre TRT1 ana haber bültenlerinde yer alan tüm haberlerde Cumhurbaşkanı R. Tayyip Erdoğan’a ayrılan konuşma süresinin oranı 
yüzde 50'dir. İkinci sırada ise yüzde 31 ile Başbakan Binali Yıldırım gelmektedir. Buna göre TRT1'in tüm haberlerinde AK Parti'li liderlere (eski ve yeni) ayrılan konuşma süresinin oranı yüzde 80'dir. CHP ve MHP'nin Genel Başkanlarına ayrılan konuşma süresi ise yüzde 20'lerdedir. 1 ila 15 Nisan tarihleri içindeki TRT ana haber bültenlerinde Şekil 8'de görülen liderler dışında, diğer siyasi parti genel başkanlarının konuşma görüntüsüne yer verilmemiştir. Dolayısıyla hem görünüm hem de konuşma süresi bakımından AK Parti temsili haberlerde çok daha fazla yer almıştır. Bu bağlamda haberlerde yer alan AK Parti'nin rakip siyasi partilere yaklaşımının tespiti önemli bir hale gelmiştir. Aşağıdaki tabloda, haberlerde yer alan siyasi partilerin birbirlerine olan eleştirel söylemlerinin niceliksel bilgileri sunulmuştur:

Tablo 8. Haberin Ana Konusu Olan Parti Tarafından Eleştirilen Parti

\begin{tabular}{|c|c|c|c|c|c|c|c|}
\hline \multicolumn{7}{|c|}{ Haberin Konusu Olan Parti Tarafından Eleştirilen Parti } \\
\hline Haber Konusu & \multicolumn{7}{c|}{ Plestilen Partiler } \\
\hline Parti & Haber Sayısı & AK Parti & CHP & HDP & MHP & Saadet & Diğer \\
\hline AK Parti & 21 & 0 & 19 & 1 & 1 & 2 & 0 \\
\hline CHP & 10 & 0 & 0 & 0 & 0 & 0 & 0 \\
\hline MHP & 2 & 0 & 1 & 1 & 0 & 0 & 0 \\
\hline Diğer Partiler & 0 & 0 & 0 & 0 & 0 & 0 & 0 \\
\hline
\end{tabular}

Tablo 8'e göre AK Parti 21 haberde konu edilmiş ve bu haberlerde CHP'yi 19 kez, Saadet Partisini iki kez, HDP ve MHP'yi de bir kez eleştiren bir dil kullanarak hedef göstermiştir. CHP'nin 10 haberinde ise eleştirdiği bir parti tespit edilememiştir. MHP toplamda iki haberde konu olmuş ve konu olduğu bu haberlerde CHP ve HDP'yi bir kez eleştirmiştir ama AKP'ye olan tutumu hakkında bir bilgi sunulmamıştır. Tablo 8'e göre diğer partiler tarafından eleştirilmeyen tek parti Ak Parti'dir. Eleştirilerin üzerindeki parti HDP ise hiçbir haberlerde Ana Aktör olarak yer almamıştır. Dolayısıyla HDP haberleri yapılmayan ama sadece eleştirilen bir parti konumunda tutulmuştur. Aynı durum Saadet Partisi içinde geçerlidir. Ayrıca Tablo 8'de ismi geçen siyasi partilerin dışında hiçbir parti araştırma tarihleri içinde TRT1 ana haber bültenlerinde yer almamıştır.

SONUÇ 
TRT’nin yayın politikası halkın belli bir kesimini ötekileştirdiğgi, azınlık olarak tabir edilebilecek gerek siyasi gerekse etnik gruplara ekranlarında kendini temsil etme yetkisinin verilmediği için çoğu kez eleştirilmektedir. Türkiye'de devlet adına radyo ve televizyon yayınlarını gerçekleştirmek amacıyla kurulan Türkiye Radyo Televizyon Kurumu'nun (TRT), 1 Nisan ile 15 Nisan 2017 tarihlerindeki TRT1 ana haber bültenlerini incelediğimiz bu çalışmada toplamda yayınlanan 224 farklı içerikteki haber, mezkur tarihler arasında yayınlanan 'tüm haberler' başlığı altında ve ana konusu referandum içerikli olan haberler 'Referandum' haberleri başlığı altında olmak üzere iki ana kategoride içerik analizi yöntemiyle analiz edilmiştir.

Araştırma tarihleri içinde 'Erhan Çelik ile TRT Ana Haber' bültenlerinde yayınlanan toplam 396 dakikalık 224 farklı içerikteki haberin, toplam süresi 77 dakika olan 45 haberin konusu '16 Nisan Referandumu' ile ilgilidir. Bu Referandum haberlerinin yüzde 76'sı günlük haber bülten sıralamasının ilk 10'u içinde izleyiciye sunulmuştur. $\mathrm{Bu}$ veriler 1şığında TRT1 ana haber bültenlerinde Referandum haberlerine özel bir önem verildiği tespit edilmiştir. TRT'nin önemli gördüğü bu 45 Referandum haberinin 38'i (yüzde 81) 'siyasetçi' aktörler üzerinden, yüzde 94 oranıyla (43 haber) 'bilgilendirici' haber söylemi üzerinden izleyiciye aktarılmıştır. Burada ortaya çıkan önemli durum yüzde 81 oranına sahip siyasetçilerin haberlerdeki görünümü ve temsilidir. Araştırmaya göre Referandum haberlerinde AK Parti temsilinin devamı olarak görebileceğimiz Cumhurbaşkanı Recep Tayyip Erdoğan 15 kez görüntülenirken, siyasi parti liderlerinden CHP lideri Kemal Kılıçdaroğlu 14 kez, AK Parti lideri Binali Yıldırım 12 kez, MHP lideri Devlet Bahçeli 3 kez, Saadet Partisi lideri Temel Karamollaoğlu 1 kez görüntülenmiştir. Diğer parti liderleri ise haberlerde hiç görüntülenmemiştir.

TRT1 ana haber bültenlerinin Referandum haberlerinde 'Evet' diyen siyasetçilerin temsili toplamda yüzde 71, 'Hayır' diyen siyasetçilerin temsili yüzde 29'dur. Bu partilerin dışında hiçbir partinin temsil görünümüne yer verilmemesi araştırmanın dikkat çeken bulguları arasındadır. Örneğin 2017 Anayasa Referandum Halkoylaması seçimlerinden bir önceki seçim 1 Kasım 2015 seçimlerinde Yüksek Seçim Kurumu'nun (YSK) verilerine göre oyların yüzde 10,56'nı alan HDP, TRT1 
ana haber bültenlerinin görünüm temsilinde hiç yer almamıştır. Dolayısıyla analizi yapılan siyasi partilerin haberlerdeki görünüm oranlarına ve temsillerine bakılarak kamu yayıncılığı yapan TRT'nin, halkın tüm kesimlerini kamusal alanda temsil etmediği ve bu çerçevede yayın yapmadığı tespit edilmiştir.

Araştırmanın dikkat çeken diğer bir bulgusu da araştırma tarihleri içindeki TRT1 ana haber bültenlerinde yaymlanan Referandum haberlerinde sivil toplum örgütleri ve kuruluşları, dernekler, vakıflar, akademisyenler, iş adamları, bağımsız kurum ve kuruluşların haberlerine yüzde 10,63 oranında pay verilirken tablo 2'de de görüldüğü gibi referandum haberlerinin yüzde 89,37'si siyasetçi (yüzde 80,85), bürokrat (yüzde \%4,26), asker (yüzde 4,26) ve polislerden (yüzde 4,26) oluşan devlet görevlileri ve yetkililerin verdiği söylemler tarafından haberleştirilmiştir. Dolayısıyla '16 Nisan Referandumu' hakkında farklı fikir ve düşüncelerin haberlerde yer alması sınırlı kalmıştır.

Araştırmaya göre, 1-15 Nisan Referandum haberlerinde en fazla konuşma süresi 16,28 dakika ile Cumhurbaşkanı R. Tayyip Erdoğan'a ayrılmıştır. Ardından sırasıyla 13,81 dakika ile AK Parti Genel Başkanı Binali Yıldırım, 6,58 dakika ile CHP Genel Başkanı Kemal Kılıçdaroğlu, 2,15 dakika ile MHP Genel Başkanı Devlet Bahçeli'nin konuşmalarına Referandum haberlerinde yer verilmiştir. Diğer siyasi parti liderlerine ise konuşma süresi ayrılmamıştır. Buna göre 'Evet' diyen siyasetçilere ayrılan toplam süre 32,24 dakika (yüzde 83), 'Hayır' diyen siyasetçilere ayrılan toplam süre ise sadece 6,58 dakika (yüzde 17) olarak tespit edilmiştir. Konuşma süresi bakımından R. Tayyip Erdoğan ve Binali Yıldırım ikilisinin temsil ettiği AK Parti'nin haberlerdeki payı yüzde 77,51'dir. Konuşmaları yayınlanan tek muhalefet parti konumundaki CHP'nin ise Kemal Kılıçdaroğlu üzerinden payı yüzde 17'dir. Dolayısıyla 'Evet' ve 'Hayır' cephesi olarak ikiye bölünen Referandum haberlerinde eşit konuşma süre dağ 11 ımı gerçekleşmemiş, aksine 'Evet' tarafina çok büyük oranda konuşma süresi ayrılmıştır.

1-15 Nisan tarihlerindeki TRT1 ana haber bültenlerinde yayınlanan sadece Referandum haberlerinin içerik analizinin sonuçlarına göre AK Parti haberlerine sayıca ve süre bakımından diğer partilere göre çok daha fazla yer verildiği, AK Parti haberlerinin özellikle içerik ve biçim olarak görsel zenginliklerle ve etkileyici 
seslerle sunulduğu, haberlerde parti kararını destekleyecek sivil röportajlara yer verildiği tespit edilmiştir. Bu bilgilerin aksine Referandum da 'Hayır' propagandası yapan tek siyasi parti olarak CHP'nin haberlerine yer verilmiştir. İçerik ve biçim olarak basit görüntü ve seslerin kullanıldığı tespit edilen CHP'nin haberleri ise sayıca ve sürece daha az olduğu gözlemlenmiştir.

1-15 Nisan tarihlerindeki TRT1 ana haber bültenlerinde yayınlanan tüm haberlerin analizinde Referandum haberlerine benzer sonuçlara ulaşılmıştır. Buna göre tüm haberlerde ana aktör olan siyasi parti yüzde 75 ile AK Parti'dir. İkinci sırada yüzde 21 ile CHP, üçüncü sırada ise yaklaşık yüzde 5 ile MHP gelmektedir. Referandum haberlerinde olduğu gibi yine bu üç parti haricindeki siyasi partilere, haberlerin hiçbirinde yer verilmemiştir. Partilerin süre dağılımda ise en fazla $\mathrm{AK}$ Parti temsil edilmiş ve 52,3 dakika ile en fazla AK Parti haberlerine süre ayrılmıştır. CHP'nin haberlerine ayrılan süre 22.45 dakikadır. MHP ise sadece üç haberde temsil edilmiş ve bu haberlerde MHP'ye 4,65 dakika süre ayrılmıştır.

TRT1 ana haber bültenlerinde yer alan tüm haberlerde Cumhurbaşkanı R. Tayyip Erdoğan'a ayrılan konuşma süresinin oranı yüzde 50 (24.16 dk.)'dir. İkinci sırada yüzde 30 (14.83 dk.) ile Başbakan Binali Yıldırım gelmektedir. Buna göre AK Parti'li liderlere (eski ve yeni) ayrılan konuşma süresinin payı yüzde 80'dir. Geriye kalan yüzdelik pay ise CHP ve MHP Genel Başkanlarının konuşma sürelerine aittir. Referandum haberlerinde olduğu gibi yayınlanan tüm haberlerde söz konusu üç parti dışında, diğer siyasi partilerin Genel Başkanlarının konuşmalı görüntüsüne yer verilmemiştir. Böylelikle konuşma süresi bakımından partilere eşit yaklaşılmadığı tespit edilmiştir.

1-15 Nisan tarihlerindeki TRT1 ana haber bültenlerinde yayınlanan haberlerde diğer siyasi partiler tarafından eleştirilmeyen tek siyasi parti AK Parti olarak dikkat çekmiştir. Buna karşı bir önceki seçimde yüzde 10,56 oranında oy alan HDP, 1-15 Nisan tarihlerindeki TRT1 ana haber bültenlerinde ana aktör olarak kendisine yer verilmemesine rağmen, sadece diğer partilerin eleştiri konusu olarak haber içeriklerinde yer aldığı saptanmıştır. 
Yukarıdaki bulgular kapsamında halkın çıkarlarını korumak ve halkın tüm kesimlerini kamusal alanda temsil etmek ve bu çerçevede yayın yapmak için organize edilmiş olan TRT'nin bir kamu kurumu olarak yayınlarını 6112'nolu hem kamu hem de ticari yayın faaliyetlerinin düzenlenmesini içeren kanunun yayın hizmetleri; “...siyasî ve felsefî düşünce, mezhep ve benzeri nedenlerle ayrımcılık yapan yayınları içeremez ve teşvik edemez...” ve “...siyasî partiler ve demokratik gruplar ile ilgili tek yönlü veya taraf tutar nitelikte yayın yapamaz" maddelerine uygun olarak yayınlarını sürdürmediği, toplumun tüm kesimlerine hitap edebilme yetisine sahip olmadığ 1 ve siyasal iktidarların etkisi altında yayınlarını sürdürdüğü tespit edilmiştir. $\mathrm{Bu}$ bağlamda demokratik bir seçim ortamında TRT'nin haber bültenleri vasıtası ile toplumun belli kesimlerini gerek çeşitli söylemler ile gerekse yok saymak sureti ile ötekileştirdiği sayısal veriler ışığında ortaya çıkartılmıştır.

Türkiye Cumhuriyeti'nin kamu yayın organı TRT'de yayınlanan haber bültenlerinde demokratik bir seçim sürecinde toplumu oluşturan tüm kesimlerin eşit söz hakkına sahip olması beklenir. Fakat yapılan analizler doğrultusunda mezkûr tarihler arasında TRT1 bir kamu iktisadi kuruluşundan beklenen yayın politikasından uzak bir yayın politikası benimsemiştir. TRT1 Haber bültenlerinde özelikle farklı fikir ve düşüncelere sahip sivil toplum örgütleri, eleştirel fikir ve görüş yapısına sahip gruplar düşmanlaştırılmak veya hedef gösterilmek sureti ile değil fakat çoğu zaman gerek görsel gerekse işitsel olarak yer verilmeyerek yok sayılmış ve ötekileştirildiği tespit edilmiştir.

\section{KAYNAKÇA}

ALTHUSSER, Louis (2002). İdeoloji ve Devletin İdeolojik Aygitları, (Çeviren: Mahmut Özışık ve Yusuf Alp), İstanbul: İletişim Yayınları.

AKSÜT, Adem (2011). Kamuyayıncılığı açısından TRT haberciliği, Selçuk Üniversitesi, Sosyal Bilimler Enstitüsü, Gazetecilik Anabilim Dall, Yayımlanmamış Yükseklisans Tezi. Konya.

ARAR, Yurdagül Bezirgan (2009). Sosyo-Politik Baglama Göre Türk Basınının “Öteki”leri, Ege Üniversitesi, Sosyal Bilimler Enstitüsü, Gazetecilik Anabilim Dalı, Yayımlanmamış Doktora Tezi. İzmir. 
ARAR, Yurdagül Bezirgan ve Nuri Bilgin (2010). "Gazetelerde Ötekileştirme Pratikleri: Türk Basını Üzerine Bir İnceleme.” İletişim Kuram ve Araştırma Dergisi, 30.

ARSAN, Esra Doğru (2004). Medya-Güç-İdeoloji Ekseninde Merve Kavakç1 Haberlerinin İki Farklı Sunumu, (Eitörler), Çiler Dursun. Haber, Hakikat Ve İktidar İlişkisi, Ankara: Elips Kitap, s. 151-182.

AVŞAR, Servet (1990). "Birinci Dünya Savaşı'nda Rus Propaganda Faaliyetleri Ve Osmanlı Devleti”, Ankara Üniversitesi Osmanlı Tarihi Araştırma ve Uygulama Merkezi Dergisi, 14, s. 65-127.

AYDOĞAN, Filiz(2004). "Kamu Yayıncılarının Editoryal Bağımsızlığı Sorunu:

Kelly Olayı'nın BBC Ve TRT Açısından Gösterdikleri.” Akdeniz Üniversitesi İletişim Fakültesi Dergisi, 2: s. 47-64.

BAYRAM, Yavuz (2015). "Bir Hak İhlali Olarak Ötekileştirme: Gazetelerin Üçüncü Sayfa Haberlerinde Suriyeli Sığınmacıların 'Öteki' Temsili’”, Güvenlik Çalışmaları Dergisi, XVII (3), s. 1-36.

CANORUÇ, Mustafa Şenay (2009). “Anayasal Kurum Olan TRT'nin "Özerkliği".”

Elektronik Sosyal Bilimler Dergisi, VIII (27), s. 293-322.

ÇAPAR, Mustafa (2006). Türkiye'de Eğitim ve Öteki Türkler, Ankara: Özgür Üniversite Yayınları.

ÇAPLI, Bülent (2002). Medya ve Etik, İstanbul: İmge Kitapevi.

ÇAPLI, Bülent (1995). Televizyon Ve Siyasal Sistem, İstanbul: İmge Kitabevi Yayınlar1.

ÇELENK, Sevilay (2010). “Ayrımcılık ve Medya.” (Editörler), Bülent Çaplı ve Hakan Tuncel. Televizyon Haberciliğinde Etik, Ankara: Fersa Matbaacılık, s.211-228.

CHOMSKY, Noam (1993). Medya Gerçeği, (Çev: Abdullah Yılmaz), İstanbul: Tümzamanlar Yayıncılık.

DOOB W., Leonard (1968). “Goebbels' Principles of Propaganda \Goebbels'in Propaganda İlkeleri.” Ankara Üniversitesi SBF Dergisi, III.(23), s. 337-366.

DURSUN, Çiler (2004). Haberde Gerçekliğin İnşa Edilmesi Ne Demektir? (Editörler), Dursun Çiler. Haber, Hakikat Ve İktidar İlişkisi, Ankara: Elips Kitap, s.37-65. 
DÜZGíT, Senem Aydın (2014). Avrupa'nın Kültürel İnşası: Alman Siyasi Söyleminde Türkiye Tartışmaları, (Editörler), Ayhan Kaya. Farklılıkların Birlikteliği Türkiye ve Avrupa'da Birarada Yaşama Tartışmaları. İstanbul: Hiperlink Yayınları s. 73-94.

EDWARD, Herman ve Noam Chomsky (1988). Manufacturing Consent; The Political Economy Of The Mass Media, New York: Pantheon Books.

EDWARD, W. Said (2004). Şarkiyatçılık; Batı'nın Şark Anlayışları, (Çev: Berna Ülner), İstanbul: Metis Yayınları.

ENSARİ, Pınar ve diğerleri. (2017) "Nefret Söylemi”, Nefretsoylemi.org, http://hrantdink.org/attachments/article/829/Medyada\%20Nefret\%20Söylemi \%20İzleme\%20Raporu\%20Ocak-Nisan\%202017.pdf, Erişim Tarihi: 04.05.2018.

EREN, Esra (2008). Kamu Yayıncılığı Ve Bir Kitle İletişim Kurumu Olarak Türkiye Radyo Televizyon Kurumu, Mimar Sinan Güzel Sanatlar Üniversitesi, Sosyal Bilimler Enstitüsü, Sinema-Tv Anasanat Dalı, Yayımlanmamış Yükseklisans Tezi, İstanbul.

FISKE, John (1997). Postmodernizm Ve Televizyon, (Editörler), Süleyman İrvan. Medya Kültür Siyaset. Ankara: Bilim Sanat Yayınları, s. 29-48.

GERAY, Haluk (2011). Toplumsal Araştırmalarda Nicel ve Nitel Yöntemlere Giriş. Ankara: Ütopya Yayınevi.

GOLDING, Peter ve Graham Murdock (2008). İdeoloji Ve Kitle İletişim Araçları: Belirlenim Sorunu, (Editörler), Levent Yaylagül ve Nilüfer Korkmaz. Medya, Popüler Kültür ve İdeoloji, Ankara: Dipnot Yayınları, s. 23-58.

GÖKÇE, Orhan (2006). İçerik Analizi Kuramsal ve Pratik Bilgiler, Ankara: Siyasal Kitabevi.

GÜLİZ, Uluç (2009). Medya Ve Oryantalizm; Yabancı, Farklı Ve Garip...Öteki. İstanbul: Anahtar Kitaplar Yayınevi.

GÜREŞÇİ, Murat (2007). Medya Söylemi ve Yeni Siyasal Politikalar Çerçevesinde Kimlik Algılaması (Ermeni Konferansının Sosyo-Politik İncelemesi), İstanbul Üniversitesi, Sosyal Bilimler Enstitüsü, Halkla ilişkiler ve tanıtım Anabilim Dalı, Yayımlanmamış Doktora Tezi. İstanbul. 
HALL, Stuart (1997). İdeoloji Ve İletişim Kuramı, (Çev: Ahmet Gürata), (Editörler), Süleyman İrvan. Medya Kültür Siyaset, Ankara: Bilim Sanat Yayınlar1.

İLHAN, Tekeli (1998). Tarih Yazıcılığg Ve Öteki Kavramı Üzerine Düşünceler, www.tarihyazimi.org, http://www.tarihyazimi.org/upload/makale/tekeli-i1998-tarih-yaziciligi-ve-oteki-kavrami-uzerine-dusunceler-26-105-

110_1527683fde48b2.pdf, Erişim Tarihi:11.07.2017.

İNCEOĞLU, Yasemin (2012). Nefret Söylemi Ve/Veya Nefret Suçları "Önsöz",

(Editörler), Yasemin İnceoğlu. Nefret Söylemi Ve/Veya Nefret Suçları, İstanbul: Ayrıntı Yayınlar1, s. 11-23.

İNCEOĞLU, Yasemin (2013). Tartışmalı Bir Kavram; Nefret Söylemi, (Editörler),

Mahmut Çınar. Medya ve Nefret Söylemi, İstanbul: Hrant Dink Vakfi Yayınlar1, s. 75-94.

İNCEOĞLU, Yasemin, ve ÇOBAN Savaş (2014). Ötekileştirme Sürecinde Medyanın Yeri, (Editörler), Yasemin İnceoğlu, Savaş Çoban. Azınlıklar, Ötekiler Ve Medya, İstanbul: Ayrıntı Yayınları, s.50-102.

KALIN, İbrahim (2016). Ben, Öteki ve Ötesi İslam-Batı İlişkileri Tarihine Giriş, İstanbul: İnsan Yayınlar1.

KARABOĞA, Tahir (2010). Medya ve Toplum İlişkileri. Ankara: Karınca Yayınları. KASIM, Metin (2011). “Hitler Döneminde Propaganda Aracı Olarak Radyo.” Selçuk Üniversitesi İletişim Fakültesi Akademik Dergisi, VI (4), s. 64-75.

KAYA, Ayhan (2014). Ötekini Anlamak Mümkün mü? (Editörler), Ayhan Kaya. Farklılıkların Birlikteliği Türkiye ve Avrupa'da Birarada Yaşama Tartışmaları, İstanbul: Hiperlink Yayınları, s. 11-40.

KAYA, Raşit (1985). Kitle İletişim Sistemleri. Ankara: Teori Yayınları.

KEANE, John (1993). Medya ve Demokrasi, (Çev: Haluk Şahin), İstanbul: Ayrıntı Yayinlar1.

KEARNEY, Richard (2012). Yabancılar Tanrılar ve Canavarlar, (Çev: Barış Özkul), İstanbul: Metis Yayınlar1.

KOCABAŞOĞLU, Uygur (1980). Şirket Telsizinden Devlet Radyosuna (TRT Öncesi Dönemde Radyonun Tarihsel Gelişimi Ve Türk Siyasal Hayatı 
İçindeki Yeri), Ankara: Ankara Üniversitesi Siyasal Bilgiler Fakültesi Yayınlar1.

MEYER, Thomas (2004). Medya Demokrasisi; Medya Siyaseti Nas1 Sömürgeleştirir? (Çev: Ahmet Fethi), İstanbul: İş Bankası Yayınları.

MORA, Nejla (2008) Kendi -Öteki- İletişimi Ve Etnomerkezcilik, Selçuk Üniversitesi İletişim Fakültesi Akademik Dergisi, V (2), s. 206-218.

MUTLU, Erol (1999). Televizyon Ve Toplum, Ankara:TRT Yayınları.

NAHYA, Nilüfer (2011). "İmgeler Ve Ötekileştirme: Cadılar, Yerliler, Avrupalılar." Atılım Üniversitesi Sosyal Bilimler Dergisi, I, s. 27-38.

NEŞE, Kars (1996). “Televizyonda Sermaye Ve Haber." Yeni Türkiye Dergisi Medya Özel Sayısı, XI (2), s. 495-523.

POYRAZ, Tuğçe, ve ARIKAN Gülay (2004). Avrupa-Türkiye İlişkileri ve Avrupa Yayılmacılığından Sonra Değişen “Öteki” Tanımları, Hacettepe Üniversitesi Edebiyat Fakültesi Dergisi, XXI (2), s. 1-16.

QUALTER, Terence (1980). "Propaganda Teorisi Ve Propagandanın Gelişimi." Ankara Üniversitesi SBF Dergisi, XXXV (1), s. 255-307.

ROBSON, Colin (2015). Bilimsel Araştırma Yöntemleri; Gerçek Dünya Araştırması, Ankara: Anı Yayınc1lık.

S. HERMAN, Edward (2003). Propoganda Modeline Dönüş, (Editörler), Robert D. McChesney, Ellen Meiksins Wood, John Bellamy Foster. Kapitalizm Ve Enformasyon Çağ1; Küresel İletişim Devriminin Politik Ekonomisi, (Çev: Nil Senem Çınga, Erhan Baltacı Ve Özge Yalçın), Ankara: Epos Yayınları. s. 223-240.

SCHILLER, Herbret (2005). Zihni Yönlendirenler, (Çev: Cevdet Cerit), İstanbul: Pınar Yayınları.

SCHNAPPER, Dominique (2005). Sosyoloji Düşüncesinin Özünde Öteki İle İlişki, (Çev: Ayşegül Sönmezay), İstanbul: İstanbul Bilgi Üniversitesi Yayınları.

TAŞÇIOĞLU, Raci (2009). Siyasetin Teknikleşmesi Bağlamında Türkiye'de Siyasal Reklamcılık, Türk Asya Stratejik Araştırmalar Merkezi, http://www.tasam.org/Files/Icerik/File/siyasetin_tekniklesmesi_baglaminda_t urkiyede_siyasal_reklamcilik_ded86b23-ec42-4b33-8b46-751dd844afad.pdf, Erişim Tarihi: 25.04.2017. 
TORUN, Ayla (2015). “Öteki İle Biz İlişkisinde Yeni Medya.”, SSHIF2015 Sosyal ve Beşeri Bilimlere ve Küresel Yaklaşımlar: Kuram ve Uygulamalar Uluslararası Sempozyumu, 16-18 Eylül 2015, VarşovalPolonya.

TRT (2017). Tarihçe, http://www.trt.net.tr/Kurumsal/Tarihce.aspx, Erişim Tarihi: 05.07.2017.

ULUÇ, Güliz, ve SOYDAN Murat (2007). Said, Oryantalizm, Resim ve Sinemanın Kesişme Noktasında Harem Suare, Bilig Dergisi, 42, s. 35-53.

VARDAL, Zeynep Burcu (2015). "Nefret Söylemi ve Yeni Medya." Maltepe Üniversitesi İletişim Fakültesi Dergisi, II(1), s. 132-156.

YAYLAGÜL, Levent (2016). Kitle İletişim Kuramları; Egemen Ve Eleştirel Yaklaşımlar, Ankara: Dipnot Yayınları.

YSK, Yüksek Seçim Kurumu (2015). Yurt İçi Seçim Sonucu, http://www.ysk.gov.tr/doc/dosyalar/docs/Milletvekili/1 Kasim2015/KesinSeci mSonuclari/96-A.pdf, Erişim Tarihi: 14.07.2018

ZIZEK, Slavoj (2011). Kırılgan Temas, (Çev: Tuncay Birkan), İstanbul: Metis Yayınlar1. 